\title{
Measuring individual material well-being using multidimensional indices: an application using the Gender and Generation Survey for Russia ${ }^{1}$
}

\author{
by \\ Daria Popova ${ }^{2,3}$ (corresponding author) \\ and \\ Alina Pishniak ${ }^{3}$
}

\begin{abstract}
This paper suggests a new and comprehensive approach to the assessment of the material well-being at the individual level by constructing a multidimensional index. Using this approach, material well-being is understood as a generic notion that covers a number of different domains, whereas the concept of domain is used to distinguish between different aspects of people's resources, including income security, basic needs, durables, housing and subjective material well-being. Each dimension is measured independently, using the best indicators available, to generate a score or domain index for each aspect of material wellbeing. The procedure of re-weighting the indicators within the separate domains enables us to account for the disparity in resources and consumer preferences across different population subgroups. The final domain scores, combined with explicit weighting, are then used to generate a summary material well-being index. The domain indices and the summary material well-being index are validated by exploring their relationships to key socioeconomic attributes, which were previously shown to be strongly associated with individual material well-being. The results showed that the summary indices of material well-being are
\end{abstract}

\footnotetext{
${ }^{1}$ This is the final version of the paper accepted for publication at Social Indicators Research. The final publication is available at Springer via http://dx.doi.org/10.1007/s11205-016-1231$\underline{7}$

2 Institute for Social and Economic Research, University of Essex, Wivenhoe park, Colchester, UK CO43SQ.

${ }^{3}$ Centre for Analysis of Income and living Standards, National Research University - Higher School of Economics, Slavyanskaya ploshyad, 4 building 2, Moscow, Russian Federation 109074.
} 
characterized by greater differentiation in relation to such measures, as occupational class and judgments of satisfaction with one's life. This allows us to conclude that our summary indices capture the latent concept of material well-being better than any of our domain indices used separately. Although the index is constructed using the Russian Gender and Generation Survey data for 2007, the methodological approach that we applied can be easily replicated in other surveys which contain information on several aspects of material wellbeing.

Keywords: material well-being; household income; multidimensional index; reference groups; Gender and Generation Survey; Russia

\section{Introduction}

There are a number of different conceptual approaches to measuring well-being at the individual level. They differ in terms of the importance attached to the individual's own judgments about his/her own well-being, and in the number of dimensions of well-being they attempt to include (Ravallion 1994). The majority of studies in applied economics and sociology, if they are not specifically devoted to the measurement of well-being, routinely rely on a unidimensional approach, whereby individual material well-being is measured by monetary measures such as disposable income or expenditures. The same approach is typically used to derive aggregate estimates of well-being at a societal level, e.g. using GDP per capita (Deaton 1997; Sen and Foster 1997). Despite the prevalence of this tradition of measuring material well-being in the systems of national statistics and cross-national comparative studies, the past few decades have witnessed an expansion of approaches based on multidimensional estimates of living standards that take into account not only income, but also non-monetary variables, such as quality of diet, availability of durables and amenities, ownership of financial assets, etc. (Stiglitz, Sen et al. 2009; OECD 2011; UNDP 2014).

This multidimensional approach to the measurement of living standards has been pioneered and developed by the literature on poverty and deprivation (Sen 1976; Townsend 1979; Mack and Lansley 1985). The indices of relative deprivation and social exclusion are essentially the composite indices of material well-being, instrumentally adjusted to poverty measurement. Numerous studies using this approach have demonstrated that definitions of poverty based on 
disparate measures of well-being, such as income, consumption and subjective economic stress, can lead to the classification of different groups of households as 'the poor', and have shown that the overlap between these groups is not as large as sometimes expected (Boarini and Mira d'Ercole 2006; Whelan and Maitre 2009; Whelan and Maître 2010; De Neubourg, De Milliano et al. 2014; Whelan, Nolan et al. 2014; Alkire, Ballon et al. forthcoming 2015).

Another implication highlighted by the poverty and deprivation literature is the relativity of the concept of well-being. The relative deprivation approach implies that individual wellbeing should be measured against the standards 'that are customary or at least widely encouraged or approved in the societies to which they belong' (Townsend 1979). This approach is grounded in the literature on subjective perceptions of well-being, and suggests that people assess their position relative to the position of their reference group, which is determined by geographical (neighbourhood) or social criteria (educational class, occupation), or a combination of these (Merton and Rossi 1968; Levitas, Pantazis et al. 2007; Whelan and Maitre 2009; Goedeme and Rottiers 2011; Bellani 2013).

These two implications are especially important in the context of developing and postsocialist economies, where income underreporting is common, and disparities in living standards between various subgroups of the population are much higher than in rich countries (Deaton 1997; Deaton and Zaidi 2002). This motivated us to create a composite index of household material well-being for Russia, which to our best knowledge is the first attempt of its kind. To a large extent this is due to the lack of household surveys which would gather information on several aspects of material well-being. This paper uses newly available and rich data on material well-being from the Gender and Generation Survey (GGS) ${ }^{1}$ for Russia. Although the proposed index is substantively linked to the Russian survey, we attempted to offer a clear measurement model that could be replicated in other GGS countries, or when using other surveys that collect information on several aspects of material well-being.

In this paper material well-being is understood as a generic notion that covers a number of different domains, whereas the concept of domain is used to distinguish between different aspects of people's resources, such as income security, basic needs, durables, housing and subjective material well-being. Our aim is to provide a measurement model that takes into account the multidimensionality and relativity of the concept of well-being, and helps to clarify how material well-being can be measured at the individual level in a more comprehensive way. We attempt to demonstrate what can be gained by applying a composite material well-being index in the analysis of the survey data, using Russia as an example. 
The next section discusses the theoretical framework providing the basis for the measurement of material well-being as a multidimensional and relative concept. The empirical analysis starts with a presentation of the data and of the methodological approach to constructing a composite index proposed in this paper, including the choice of indicators, weighting and aggregation. In the results section we move on to the analysis of the Russian household survey and describe various choices that had to be made, to ensure the reliability and robustness of the composite index. Then we test the validity of our composite measure by correlating it with other variables that were previously shown to be associated with material well-being. The last section summarizes the results of the analysis and provides some suggestions for future research.

\section{Theoretical framework}

Despite the growing number of studies on multidimensional measurement of economic wellbeing, many examples of which can be found in the specialized journals, such as Social Indicators Research and Quality of Life Research, the tradition of measuring well-being using monetary indicators, e.g. disposable income or expenditure, is still prevalent in national statistics, international comparisons and academic research. This tradition is rooted in the welfarist approach, which equates the maximization of welfare and the maximization of factors of consumer utility (Ravallion 1994).

In contrast, non-welfarist approaches pioneered by A. Sen (1976) and P. Townsend (1979) prefer to base welfare assessments on individual levels of well-being across a number of dimensions, such as food, clothing, housing, etc. In this tradition well-being is defined in terms of a number of basic needs which are measured by non-monetary indicators. The construction of these indicators implies the identification of a list of basic needs that must be satisfied and a minimum level of satisfaction of these needs. The resulting indicators are then aggregated in a composite index by summing up the indicators for each individual (Mack and Lansley 1985). The resulting indices of multiple deprivation and social exclusion (Nolan and Whelan 1996; Gordon, Adelman et al. 2000; Whelan and Maître 2010) are essentially the composite estimates of well-being, instrumentally adjusted to poverty measurement.

The multidimensional approach is shared by some scholars working with monetary measures of well-being, such as income and consumption. For example, Deaton suggests that measures of individual well-being should be based on consumption aggregates that take into account 
the consumption of food and non-food items, as well as the value derived from the consumption of durables and from home-ownership (1997). Ravallion goes further to suggest that under certain conditions monetary poverty can also be interpreted as a multidimensional phenomenon (2012). This interpretation can be found, in particular, in the works of one of the first researchers of poverty, J. Rowntree. The latter defined poverty as the lack of financial resources necessary for the provision of the minimum level of consumption of food, clothing and other vital domains of life (Rowntree 1901). The line between the poor and non-poor, therefore, is drawn on the basis of the definition of domains of consumption (e.g. food, clothing, housing, social services, etc.) that are crucial for survival and/or an adequate life; and the assessment of the financial resources that are necessary to obtain the minimum level of consumption within each domain. Thus, monetary poverty is only one specific case of multidimensional poverty, where the weights of domains are defined on the basis of prices of various consumer goods, multiplied by the number of goods required to meet the minimum requirements. The aggregation of domains is made by summing up the value of consumer goods across all the domains.

The main limitation of the unidimensional monetary approach to measuring individual wellbeing is that the availability of financial resources does not always guarantee access to consumer goods and services. This may occur because of lack of services and infrastructure, lack of information, administrative barriers, discrimination, etc. (De Neubourg, De Milliano et al. 2014). In contrast, access of households to certain goods and services might be provided for free or at a discounted price. For instance, the availability of free public health care and education means that the household does not need additional financial resources to meet these basic needs. At the same time, households may consume more than their disposable income can afford due to the fact that a part of consumption can be covered by in-kind interhousehold transfers and home production of food, especially in the rural area.

Numerous studies have demonstrated that when material well-being is defined using a single criterion, such as disposable income, basic needs, or subjective economic stress, different groups of households are classified as poor, and the overlap between those groups is quite small (Boarini and Mira d'Ercole 2006; Whelan and Maitre 2009; Whelan and Maître 2010; De Neubourg, De Milliano et al. 2014; Whelan, Nolan et al. 2014; Alkire, Ballon et al. forthcoming 2015). Although experiencing poverty in one well-being domain increases the chances of being deprived in other domains, this is not the case for all individuals. These results have raised an awareness of the limitations of using unidimensional measures to 
monitor societal progress in living standards. For example, in 2010 the European Union adopted the 2020 Poverty and Social Exclusion Target, which employs a multidimensional measure combining three indicators (relative income poverty, material deprivation and household joblessness). The OECD has produced a Better Life Index (OECD 2011), which allows it to compare 34 OECD member states by their levels of material well-being (GDP per capita), as well as by several non-income related dimensions of well-being, such as the access to employment, the quality of education, housing, environment, etc. The UNDP, which produces the well-known multidimensional Human Development Index, has launched a new Multidimensional Poverty Index, designed to complement the measures of income poverty by a set of measures reflecting deprivation in access to health, education and decent living conditions (UNDP 2014).

As far as the second implication of the basic needs approach is concerned, individual wellbeing should be measured against the standards 'that are customary or at least widely encouraged or approved in the societies to which they belong' (Townsend 1979). There is strong evidence to suggest that the concepts of poverty/wealth are related to individual perceptions, rather than to objective states. The idea originates in R. Merton's reference group theory, according to which people's assessment of their position is always relative, i.e. depends on the income level of their reference group, which may be determined by geographical (neighborhood) or social criteria (educational class, occupation), or a combination of these (Merton and Rossi 1968). The reference group theory has been further developed in studies of social exclusion, which imply that individual well-being is affected by opportunities of access to financial resources, activities, consumer goods and services that are available to the majority of the population in the given jurisdiction (Levitas, Pantazis et al. 2007). In other words, well-being is determined by the relative position of an individual in a society, rather than by objective factors (Whelan and Maitre 2009; Goedeme and Rottiers 2011) and has to be assessed in relation to the situation of his/her reference group, i.e. other individuals with similar socio-demographic characteristics, with whom he/she interacts on a regular basis (Bellani 2013). Interestingly, researchers working with traditional monetary measures also point out that the weights of different domains in the overall welfare aggregate should be defined in a relative manner: i.e. separately for individual countries or regions, because of the regional disparities in the cost of living, tastes and preferences of the populations, as well as the prevailing norms in consumption (Deaton and Zaidi 2002). 
The reference group theory has some important implications for the ongoing debate about the importance of objective and subjective measures of well-being. The former represent social facts independent of personal evaluations (e.g. level of income, number of durables, quality of housing, etc.), while the latter are measures of individual perceptions and evaluations of living conditions (e.g. a self-assessed ability to make ends meet, satisfaction with one's life, etc.). Since, as shown above, objective properties are experienced trough subjective assessment of individuals, both classes of indicators serve their purpose only if used in combination (Pantisano, Craglia et al. 2014).

Apart from the conceptual considerations, there are some methodological issues connected with the way income data are collected in household surveys. The measurement of income in surveys is often associated with various statistical problems. These include income underreporting, when some households participating in the survey do not report all incomes; an item non-response, when some households do not report income at all; and a unit nonresponse, when some households do not participate in surveys even when selected in the survey sample. These three phenomena can, potentially, seriously affect the estimation of household income, especially at the upper end of income distribution. While there is no obvious solution for the third type of bias (unit non-response), using income in combination with additional material well-being indicators can help to control the first two problems (income underreporting and item non-response) and to increase the reliability of the wellbeing analysis.

This is especially important in the context of developing and post-socialist economies with a large non-observed economy (Deaton 1997; Deaton and Zaidi 2002). The research on Russia, in particular, often has to deal with income underreporting and volatility (Ovcharova and Tesliuk 2006; Gorodnichenko, Sabirianova Peter et al. 2010; Gimpelson and Kapeliushnikov 2011; Popova 2013). According to the national statistics agency (Rosstat), throughout the 2000s earnings hidden from statistical observation, i.e. unreported earnings, made up about $30-40 \%$ of official (declared) earnings, ranging from less than $15 \%$ in the bottom income decile to over $50 \%$ in the top income decile (UNDP 2011). These unreported earnings are imputed and included as an element of total population income in macro-statistics ${ }^{2}$. In fact Rosstat's Household Budget Survey, which serves as a source for official estimates of inequality and poverty, has not collected any data on incomes since 1997, because they are considered a priori unreliable. 
A few studies which applied a multidimensional approach to poverty in Russia have shown results that are similar to those obtained in studies for OECD and EU countries - namely, the small overlap between income poverty, deprivation poverty and subjective poverty (Ovcharova and Popova 2005; UNICEF 2011). Hence, a multidimensional approach to measuring household material well-being is likely to provide a more comprehensive and reliable assessment of living standards in Russia than unidimensional measures, such as income. The reference group theory, which holds that resources of households should be assessed in relation to households with similar socio-demographic characteristics, provides another important input in the Russian context, where income disparities and disparities in the cost of living are particularly high.

\section{Data}

This paper uses data from the Gender and Generation Survey (GGS) for Russia for 2007. GGS is a multi-topic survey primarily focused on demographic behaviour, but it also contains an extended set of variables on material well-being, which so far have not been available in any other survey conducted in Russia. Overall, we were able to draw 25 well-being indicators: this makes GGS a unique source of data for this kind of study. The survey satisfies international standards in terms of sampling and quality of data collection. It is based on a three-stage probability sample drawn from the population of dwellings ${ }^{3}$. In each dwelling one household was selected for an interview and within each household interviews were conducted with one randomly selected individual aged 21-82 years. Therefore, the GGS sample is suitable for analysis at both household and individual levels. In addition, a part of the GGS sample is compatible with the sample of Russian Longitudinal Monitoring Survey (RLMS-HSE) ${ }^{4}$. This enables us to draw additional information from RLMS-HSE, in order to construct some of the well-being indicators which are missing in GGS. The analysis in this paper is based on the $2007^{5}$ cross-sectional sample of 11,117 households/individuals.

\section{Methodology of constructing a material well-being index}

The procedure for constructing the index includes the following steps:

(1) on the basis of the contextual analysis of GGS data the indicators of material well-being are selected; 
(2) the indicators are combined to form separate domains of material well-being, and for each domain a separate index is calculated;

(3) the domain indices are combined to form an overall material well-being index.

We identified five domains, each reflecting a particular aspect of material well-being: income security, basic needs, durables, housing and subjective material well-being. Our choice of the type and number of well-being domains was driven by both the statistical structure of the dataset and conceptual considerations. It is generally agreed that monetary measures, such as disposable income and expenditures, even if they could be measured with perfect accuracy, are limited in their scope, but are nevertheless a central component of any assessment of living standards (OECD 2011; Land, Michalos et al. 2012; UNDP 2014). Indicators of deprivations/basic needs are used to capture current consumption capacities of the household, incorporating a subjective evaluation as to whether they are doing without a particular item due to inability to afford (Nolan and Whelan 1996). Long-lived assets such as housing and consumer durables which require large and relatively rare expenditure are considered as a good proxy for living standards of the household in the long run (Deaton 1997). Subjective estimates of their own material well-being by the respondents can be a useful complement to more objective data as they can affect household behaviour (OECD 2013). Thus, our overall material well-being index combines monetary and non-monetary, objective and subjective, short-term and long-term well-being indicators, which altogether are expected to increase the reliability of the overall measure. ${ }^{6}$

Given the conceptually different nature of our domains, it is important to avoid an overlap of indicators across the domains. For example, the presence of arrears (in paying rent and utility bills) and savings may be used as indicators within the domains of either income security or basic needs. We opted for using them in the income domain, although the other option can also be justified ${ }^{7}$. This approach allows us to avoid the need to define causal links between different dimensions of material well-being (e.g. between income and housing) and enables us to make reasonable decisions about the weight of different domains within the composite index.

Each domain index consists of a number of indicators that should comprehensively capture relevant dimensions of material well-being within the constraints of data availability, i.e. satisfy the following criteria:

- to be domain specific, i.e. to be direct indicators of that aspect of material well-being; 
- to reflect aspects of material well-being that are observed in all sample units, rather than some specific group of the population;

- to be defined for the whole sample.

The income security domain is represented by a single indicator - per capita income - which is adjusted using two additional income security indicators to make it more robust. Other material well-being dimensions are measured by composite indices comprising a number of indicators, reflecting whether or not the household has or can afford certain items/activities (seven in basic needs, ten in durables, five in housing and two in subjective well-being). The procedure for aggregating indicators into a domain index includes the following steps:

Step 1: to define whether an item is available or not;

Step 2: to define the weight of each item;

Step 3: to sum up all the items that are available to the household.

A domain index is calculated using the formula below:

$$
I_{W} \equiv \frac{\sum a_{i} x_{i}}{\sum a_{i}} \times 100
$$

where $x$ is an item ( 1 if available; 0 if not available); $a$ is the weight of an item; $i$ is the number of items included in the index. The reliability of a domain is tested using the Cronbach coefficient Alpha (Cronbach 1951), which shows how well a set of items measures a certain latent concept. The generally accepted reliability thresholds vary by discipline, but typically lie within the range of $0.6-0.8$, with an average value of 0.7 (OECD 2008). A final domain index is a continuous distribution of scores from 0 to 100, with those lacking all items scoring 0 , and those having all items not owned by anybody else potentially scoring 100.

In order to put domains on the same metric numerical scores are transformed into ranks. This method is not affected by outliers and allows comparing the performance of individuals across various well-being domains in relative terms (OECD 2008). These untransformed ranks were standardized by dividing each rank by the maximum rank of the domain and multiplying this by 100 .

The aggregation of variables within the composite index can be performed by giving all variables the same weight, assuming that all variables make the same contribution to the 
composite index. This is a fairly common practice which could disguise the absence of an empirical basis or a theoretical model (OECD 2008). The other approach is to use weights which reflect the relative importance of each variable for the composite index (Willitts 2006). The weights can be chosen arbitrarily, determined by policy priorities or theoretical factors or derived empirically (Hallerod 1994).

We wanted to avoid making any value judgements regarding the relative importance of various aspects of well-being by relying on an empirical approach. In order to combine various indicators within the separate domains indices we applied the prevalence weighting approach, whereby the presence of each item is weighted by the proportion of households that cannot afford that item ${ }^{8}$. This approach enables us to take into account the cost of items as well as individual preferences: those items owned most widely are likely to be the most affordable and thus will have a lower weight than those items that are affordable to fewer households (Decancq and Lugo 2013). Following the reference group theory, the weights were additionally adjusted by taking into account differences in needs and preferences between various population subgroups. To a certain degree, this procedure is analogous to the adjustment of household income using an equivalence scale or regional/temporal price indices, in order to eliminate differences in the cost of living. The weights were adjusted using the combination of two criteria - the geographical area (the large regional centres, other cities, urban settlements and rural settlements) and household composition (households of working age people with children under 18 years; households of working age people without children; and households of pensioners without children). Accordingly, the weight for each item had twelve values. Other combinations were tested but those chosen here appeared to be optimal in terms of the group size ${ }^{9}$. In addition, they provided the highest variability in terms of values of the weight variable (i.e. the proportion of people who could not afford certain items), which guaranteed higher variability in the domain scores. This is desirable because later on numerical scores within separate domains are transformed into ranks, before they are combined in an overall well-being index. Hence, a higher variability of the weights helps to achieve a higher number of unique ranks in the composite indices. The $\chi^{2}$ test was applied to confirm that the differences between the selected subgroups were statistically significant. Overall, the higher the average proportion of households deprived of an item in the reference group, the more the ability to afford it contributes to the domain index ${ }^{10}$.

In order to combine the separate domain indices in the overall well-being index, we relied on Factor analysis (using the Maximum Likelihood method) to derive weights for their 
combination. This method was chosen to reflect the statistical quality of the data, as it allowed us to assign higher weights to more statistically reliable domains of well-being (Jacobs, Smith et al. 2004). It gave us control over the degree of compensability in the composite index, whereby low scores in some domains can be compensated by high scores in other domains (Nardo, Saisana et al. 2005). By assigning lower weights to less reliable domain indices we achieved some degree of non-compensability for a deficit in more reliable domains, and vice versa. The advantage is that the reliability of the overall well-being index is improved by giving more weight to more reliable domains.

The domain indices and overall material well-being indices are validated by exploring their relationships to key socio-economic attributes, which were previously shown to be strongly associated with individual material well-being, i.e. occupational class (Breen 2005; Grusky and Weeden 2008), family composition (Rig and Sefton 2006) and life satisfaction (Schokkaert 2007).

\section{Results}

A step-by-step procedure for the construction of the summary index of material well-being is given below. All tables and figures are based on GGS-2007 unless indicated otherwise.

\section{Income}

GGS contains a relatively detailed battery of questions about all types of personal income of the respondent and his/her partner/spouse for the last 12 months (including income from employment and self-employment, pensions, scholarships and social benefits, alimonies and child maintenance from previous partners). In addition, the respondents were asked to indicate either the annual household income from all sources or the average monthly income from all sources for the past 12 months. Thus if the respondents did not report the total household income or if the total household income was below the sum of the components, including the personal income of the respondent and his/her partner and cash transfers received from other people ( $8.5 \%$ of all households), the final income indicator was adjusted using these data. Per capita incomes that were lower than 1/10 of median per capita incomes in the household's region and area (capital city/other urban/rural) were substituted by this value (1\% of observations). For households that did not provide any information about their incomes $(2.8 \%)$ they were predicted using a linear regression model ${ }^{11}$. Finally, our income indicator was adjusted for the inter-regional disparity in the cost of living using the ratio of 
the federal and regional minimum consumer baskets in the second quarter of $2007^{12}$. Our final income indicator is measured in per capita terms ${ }^{13}$.

Table 1 - The adjustment coefficients for per capita income

\begin{tabular}{|c|c|c|}
\hline Decile groups by per capita income: & $\begin{array}{c}\text { arrears in paying rent } \\
\text { and utility bills }\end{array}$ & savings \\
\hline 1 (with the lowest income) & 0.46 & 1.01 \\
2 & 0.91 & 1.04 \\
3 & 0.94 & 1.04 \\
4 & 0.98 & 1.03 \\
5 & 0.93 & 1.04 \\
6 & 0.97 & 1.05 \\
7 & 0.97 & 1.05 \\
8 & 0.95 & 1.05 \\
9 & 0.98 & 1.07 \\
\hline (with the highest income) & 0.99 & 1.04 \\
\hline
\end{tabular}

Since per capita income is the only indicator in the income domain, we attempted to improve the robustness of the domain and the ranking within the domain by using some additional indicators of income security ${ }^{14}$. The first one was derived from the question 'Has your household been in arrears at any time during the past 12 months, that is, unable to pay as scheduled any of the following... '. 16.4\% of all households indicated that they were unable to pay rent or utility bills. We did not take into account mortgage arrears because those were reported by a very small number of households in the GGS-2007 sample. Our assumption is that the inability to pay rent/utility bills implies an acute shortage of cash income, hence, other conditions being equal, households that were in arrears are worse-off than those that did not report any arrears. The second indicator is based on the question 'Considering your household's income as well as expenses: is there normally some money left that you could save?'. $31.7 \%$ of all households reported that they were able to save money. Other conditions being equal, we assume that households that can make savings are better off than those that cannot. $2.4 \%$ of households reported that they were able to make savings and were in arrears at the same time. Based on the above-mentioned assumptions we have computed the adjustment coefficients for household income equal to (1) the ratio of rent and utility bills debt and total household income, and (2) the ratio of savings and total household income. Since there were no data on the amounts of debts/savings in GGS, we have calculated these ratios for each income decile using RLMS-HSE data for the same year (Table 1). If the 
household reported debts or savings, its income was multiplied by the adjustment coefficients for a respective income decile. Although the differences between the deciles are rather small (apart from the bottom decile), this procedure still affects the ranking of households and this is important because later on numerical scores within separate domains are transformed into ranks, before they are combined in an overall well-being index.

\section{Basic needs}

GGS collects information on whether the household can or cannot afford eight items listed in Table 2. The wording of the question enables us to distinguish between the enforced lack of an item ('cannot afford') and the lack of an item due to choice ('do not have for other reasons'). The separate items were combined into the domain index using Formula 1, with the weights accounting for the relative variation in needs across twelve population subgroups (Annex, Table 1). The weights denominator is the number of households that cannot afford an item. For instance, the proportion of households that cannot afford to buy new clothes amounts to $8.1 \%$ on average across the sample. However, among the families of working age people without children living in regional centres, this share reaches almost $44 \%$, while among households of pensioners it is just $6.8 \%$. This reflects the difference in both resources and consumer preferences of these groups, and will be accounted for in the summary measure by our weighting scheme.

The set of indicators for the basic needs domain is internally consistent (overall Cronbach's alpha is above 0.800). However, it appears that after the exclusion of one item ('keeping home adequately warm') the Cronbach's alpha for the overall measure increases from 0.809 to 0.814 . This happens because this item is available to the majority of the population and its inclusion does not add any additional variance to the summary measure. Also, the item-total correlation coefficient for this item is substantially lower as compared to other items (it is 0.295 while for the rest of items it is always above 0.500). This item does not correlate very well with the overall scale, thus, it may be dropped. Ultimately, the domain index comprises seven items, with weights varying across the population subgroups. The index values range from 0 to 100 . 
Table 2 - Indicators and reliability analysis of the basic needs domain

\begin{tabular}{|l|cc|cc|}
\hline \multirow{2}{*}{} & \multicolumn{2}{|c|}{$\begin{array}{c}\text { Proportions of households } \\
\text { that: }\end{array}$} & \multicolumn{2}{c|}{ Reliability analysis } \\
\cline { 2 - 5 } & can afford $\quad \begin{array}{c}\text { cannot } \\
\text { afford }\end{array}$ & $\begin{array}{c}\text { corrected } \\
\text { item-total } \\
\text { correlation }\end{array}$ & $\begin{array}{c}\text { Cronbach's } \\
\text { Alpha if } \\
\text { item } \\
\text { deleted }\end{array}$ \\
\hline keeping home adequately warm & $87.6 \%$ & $12.2 \%$ & 0.295 & 0.814 \\
buying new, rather than second-hand clothes & $81.6 \%$ & $18.1 \%$ & 0.523 & 0.788 \\
eating meat, chicken or fish every second day & $75.5 \%$ & $24.4 \%$ & 0.509 & 0.789 \\
$\begin{array}{l}\text { paying for health care services, except for an expensive } \\
\text { surgery, if necessary }\end{array}$ & $57.3 \%$ & $42.5 \%$ & 0.533 & 0.786 \\
having friends or family for a drink or meal at least once & $48.7 \%$ & $51.2 \%$ & 0.597 & 0.776 \\
a month & $44.1 \%$ & $55.7 \%$ & 0.621 & 0.771 \\
replacing any worn-out furniture & $35.3 \%$ & $63.9 \%$ & 0.551 & 0.783 \\
paying for education of household members if necessary \\
paying for a week's annual holiday away from home
\end{tabular}

\section{Durables}

The domain seeks to measure household assets in the long term by analysing the availability of durables, a car and a second home. GGS collects the data on possession ${ }^{15}$ of eleven items and the wording of the question allows us to distinguish between families that do not possess items due to lack of money or due to their preferences (Table 3). The separate items were combined into the domain index using Formula 1, taking into account the variation in weights of items across 12 groups of households (Annex, Table 1).

The overall Cronbach's alpha of 0.693 allows us to conclude that the scale is reliable. However, the exclusion of one item ('dishwasher') increases the reliability of scale (Cronbach's alpha rises to 0.697 ). This item also appears to be poorly correlated with the rest; the item-total correlation is twice as low as for any other item. This does not mean that the presence of a dishwasher is not important in terms of material well-being, but given that only $1.2 \%$ of households reported having a dishwasher and $69.3 \%$ of households do not have it 'for other reasons', its exclusion from the scale appears to be reasonable. It is noteworthy, although a similarly high percentage of households do not have a second car for other reasons rather than the lack of money, the removal of this item would reduce the reliability of the scale. Thus, the final domain index comprises ten items. The index scores range from 0 to 100. 
Table 3 - Indicators and reliability analysis of the durables domain

\begin{tabular}{|c|c|c|c|c|c|}
\hline & \multicolumn{3}{|c|}{ Proportions of households that: } & \multicolumn{2}{|c|}{ Reliability analysis } \\
\hline & have & $\begin{array}{l}\text { would } \\
\text { like to } \\
\text { have but } \\
\text { cannot } \\
\text { afford }\end{array}$ & $\begin{array}{l}\text { do not } \\
\text { have for } \\
\text { other } \\
\text { reasons }\end{array}$ & $\begin{array}{l}\text { corrected } \\
\text { item-total } \\
\text { correlation }\end{array}$ & $\begin{array}{l}\text { Cronbach's } \\
\text { Alpha if } \\
\text { item } \\
\text { deleted }\end{array}$ \\
\hline a colour TV & $96.6 \%$ & $2.3 \%$ & $1.1 \%$ & 0.250 & 0.687 \\
\hline a washing machine & $85.4 \%$ & $9.7 \%$ & $4.8 \%$ & 0.311 & 0.677 \\
\hline a telephone (landline or mobile) & $85.2 \%$ & $8.4 \%$ & $6.3 \%$ & 0.384 & 0.665 \\
\hline a video recorder or DVD player & $66.2 \%$ & $13.3 \%$ & $20.5 \%$ & 0.493 & 0.642 \\
\hline a microwave & $39.2 \%$ & $30.9 \%$ & $29.9 \%$ & 0.487 & 0.643 \\
\hline a car or a van available for private use & $33.4 \%$ & $31.9 \%$ & $34.7 \%$ & 0.441 & 0.653 \\
\hline a home computer, laptop & $33.1 \%$ & $30.5 \%$ & $36.4 \%$ & 0.462 & 0.649 \\
\hline a second home (e.g. a summer cottage) & $16.3 \%$ & $31.7 \%$ & $52.0 \%$ & 0.237 & 0.689 \\
\hline $\begin{array}{l}\text { a second home (e.g. house, flat, winter } \\
\text { cottage) }\end{array}$ & $7.8 \%$ & $42.9 \%$ & $49.3 \%$ & 0.216 & 0.689 \\
\hline a second car & $4.5 \%$ & $29.8 \%$ & $65.7 \%$ & 0.263 & 0.685 \\
\hline a dishwasher & $1.2 \%$ & $29.6 \%$ & $69.3 \%$ & 0.120 & 0.697 \\
\hline Cronbach's Alpha & & & & & 0.693 \\
\hline
\end{tabular}

\section{Housing}

The approach to measuring well-being in terms of housing is not different from that applied to basic needs and durables (see Formula 1), except for the fact that indicators do not come as a battery of questions. There is more than one potential approach to the measurement of housing material well-being, and many possible indicators. One approach might be to focus on ownership and accessibility of housing, while another might be to identify poor quality and overcrowded housing. We attempted to combine these two approaches in one summary measure of housing. Below we describe the indicators (Table 5). The weights of indicators are presented in Annex, Table 1.

We start with an indicator of home ownership. The specificity of the Russian housing market is that the majority of families are either homeowners or tenants renting their accommodation from the state or municipality, and thus paying lower rents, and only a minor part of the population rents accommodation from private firms or persons, paying the market rent ${ }^{16}$. According to GGS, $64.6 \%$ of all households in the sample are homeowners. Another $30.4 \%$ of households live in state/municipal accommodation, paying low rents, or in rent-free accommodation provided for them by relatives; hence the level of housing-related expenses does not differ much from that of homeowners. Only 5\% of households reported renting private accommodation and paying the market rent. Other conditions being equal, it is reasonable to assume that homeowners are better off than tenants, thus our first indicator 
equals 1 for homeowners and 0 for all others ${ }^{17}$. The indicator is weighted by the proportion of households renting housing on the market, varying across twelve population subgroups. Since this proportion on average is small (5\%), the average weight of this indicator in the summary housing domain will be low, but it will be higher in regional centres where the housing market is more developed compared to other settlement types, and for families with children, who are more likely to be tenants, compared to pensioners. As far as pensioners are concerned, there are practically no cases of living in a rented home, so the weight of this indicator for this group of households will be 0 .

The next indicator is the availability of separate accommodation, which equals 1 if a household lives in a separate house/flat and 0 if it does not. The indicator is weighted by the proportion of households that cannot afford separate accommodation. The situation where several nuclear families have to share the same flat or house is characteristic of $7.9 \%$ of households, but these proportions are much higher in cities and for households with children. Accordingly, the weight of this indicator for these groups of households will be higher than for rural and pensioners' households.

Now we turn to the characteristics of quality of housing, starting with the availability of amenities. GGS collects data on seven types of amenities. The lack of one or several items from the list was treated as a sign of poor quality of housing, hence low material well-being. Based on the results of reliability analysis, one of the items ('toilet without central plumbing') was excluded from the summary measure. The overall Cronbach's alpha for the 6-item index equals 0.900 , which signifies very high internal consistency. No weights were applied as we considered that all amenities are equally important. The final indicator equals 1 if all the amenities are available, and 0 if at least one item is lacking. On average $40.8 \%$ of Russian households live in low quality dwellings. This indicator does not differ across demographic groups, but has a particularly high disparity across types of settlement: in regional centres the proportion of inadequate housing is below $20 \%$, while in rural settlements it reaches over $80 \%$. Accordingly, in urban areas where amenities are not a rare thing, this indicator will have a lower weight in the final domain index, while in rural areas where the housing in general is of worse quality it will have a higher weight. 
Table 4 - Indicators and reliability analysis of the indicator of availability of amenities

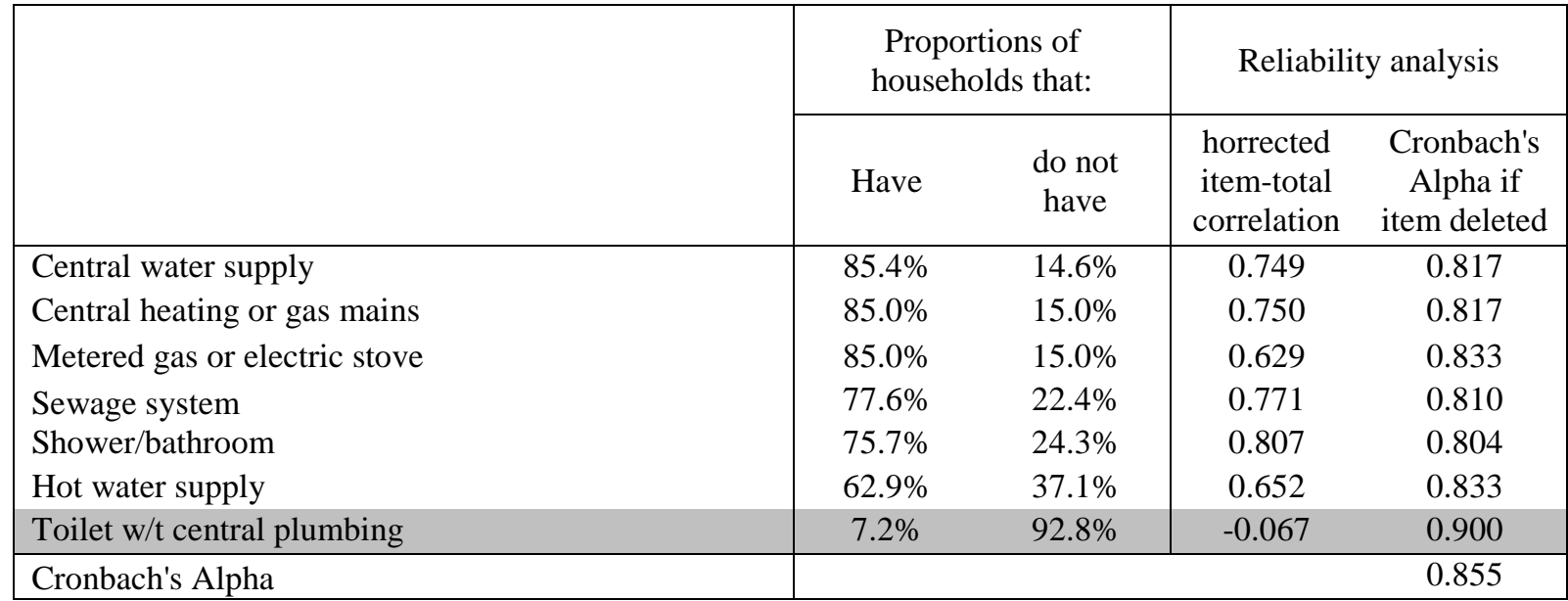

Two other indicators of housing material well-being are related to living space. GGS collects information about the size of living space. Here the federal social standards of living space were used as a reference point as to what constitutes a minimum adequate living space for households of different sizes ${ }^{18}$. If the total living space in relation to the household size is equal or higher than the federal social standard, the indicator equals 1 , if the living space is below the standard, the indicator equals 0 .

Another indicator of living space was the number of rooms in the dwelling (excluding kitchens, bathrooms, toilets, rooms used solely for business, hallways and utility rooms). To compare households of different sizes and demographic composition we applied the following formula:

Number of rooms per household of an equivalent size $=$ number of rooms / (number of adults without partner $* 1+$ number of adults with partner $* 0.5+$ number of children below 18 years $* 0.5)$

In other words, the denominator contains the number of household members, adjusted using the equivalence scale, which was developed to account for the housing standards characteristic for Russia. These standards should be adjusted to national conditions if the methodology is to be replicated in a different country. According to this scale, the minimum number of rooms for a childless couple equals 1 , for a couple with 1 child -1.5 , for a couple with 2 children -2 , for two adults not related by partnership - 2, etc. The modal value (1 room per equivalent member) was taken as a threshold to create an indicator. The indicator equals 1 if the rooms' availability equals 1 or more, otherwise it equals 0 . A low number of 
rooms is characteristic of $22.9 \%$ of Russian households, but this average value hides a large disparity across the population subgroups. Pensioners' households are relatively well-off in terms of rooms' availability; hence for this group the weight of this indicator in the summary housing index will be close to 0 . In contrast, more than a half of households with children living in cities and a third of families in rural area and urban type settlements lack rooms. For these categories of households the indicator will have a higher weight in the summary index.

Table 5 - Indicators and reliability analysis of the housing domain

\begin{tabular}{|c|c|c|c|c|}
\hline & $\begin{array}{r}\text { Propo } \\
\text { househ }\end{array}$ & $\begin{array}{l}\text { lons of } \\
\text { ds that: }\end{array}$ & Reliabilit & analysis \\
\hline & have & $\begin{array}{l}\text { do not } \\
\text { have }\end{array}$ & $\begin{array}{l}\text { corrected } \\
\text { item-total } \\
\text { correlation }\end{array}$ & $\begin{array}{c}\text { Cronbach's } \\
\text { Alpha if } \\
\text { item } \\
\text { deleted }\end{array}$ \\
\hline own accomodation & $73.8 \%$ & $26.2 \%$ & 0.268 & 0.233 \\
\hline separate accomodation & $92.1 \%$ & $7.9 \%$ & 0.173 & 0.211 \\
\hline an adequate number of rooms & $77.1 \%$ & $22.9 \%$ & 0.260 & 0.049 \\
\hline accommodation equipped with all necessary amenities & $59.2 \%$ & $40.8 \%$ & -0.008 & 0.347 \\
\hline $\begin{array}{l}\text { accommodation with the living area equal to or above the } \\
\text { social standard }\end{array}$ & $46.9 \%$ & $53.1 \%$ & 0.178 & 0.132 \\
\hline Cronbach's Alpha & & & & 0.245 \\
\hline
\end{tabular}

As in other composite domains, the summary housing index, including five indicators, was tested for internal consistency. The indicators turned out to be weakly positively correlated with each other, with the overall Cronbach's alpha for five items reaching 0.245. This was expected, because our indicators were a mix of ownership and quality of housing characteristics. Note that indicator of amenities has the lowest item-total correlation value (0.008), which indicates that it is not measuring the same construct as the rest of indicators. However, even if the indicator of amenities is deleted, the Cronbach's alpha would rise to 0.347, which is still well below the acceptable reliability thresholds. This reflects the specificity of the Russian housing market, where housing ownership (which is quite widespread due to privatization in the 1990s) is weakly correlated with housing quality, and housing quality characteristics such as the availability of amenities and the living space are weakly correlated with each other (i.e. houses in rural area are more spacious, but poorly equipped with amenities, while in urban areas accommodation is equipped with amenities, but is typically of a smaller size). Since the elimination of either of these indicators would not 
help us raise the overall reliability of the housing domain, we chose to keep all five items within the summary housing index for further investigation, keeping in mind that the reliability of the housing index is low.

\section{Subjective material well-being}

Subjective estimates of their own material well-being by the respondents are generally considered to be unreliable measures if used on their own, as they are typically found to be weakly correlated with objective well-being indicators. For example, evidence suggests that the impact of deprivation on subjective economic stress is greater in more affluent countries because individuals assess their well-being relative to others (Whelan and Maitre 2009). That is why we have opted for keeping subjective indicators within a separate domain. In this way we can control whether and how they should be taken into account in the final material wellbeing index.

GGS contains only two questions that can be used as indicators for the subjective material well-being domain. The first question is 'How easily do you make ends meet?' with a 6-item response scale ${ }^{19}$, and the second question is 'How would you describe your living conditions?' with a 5-item response scale (Table 6).

Table 6 - Distribution of responses to questions about subjective assessment of household material well-being

\begin{tabular}{|l|c|}
\hline Thinking of your & \\
household's total monthly & $\%$ \\
income, is your household & \\
able to make ends meet ... & \\
\hline very easily & 0.2 \\
easily & 3.3 \\
fairly easily & 9.7 \\
with some difficulty & 41.7 \\
with difficulty & 25.7 \\
with great difficulty & 19.4 \\
\hline
\end{tabular}

\begin{tabular}{|l|c|}
\hline $\begin{array}{l}\text { How would you } \\
\text { describe your } \\
\text { living conditions... }\end{array}$ & $\%$ \\
\hline very good & 3.8 \\
good & 33.4 \\
\hline satisfactory & 49.0 \\
bad & 11.2 \\
very bad & 2.6 \\
\hline
\end{tabular}

The domain index is calculated using the same formula as for the other composite domains (see Formula 1). The original Likert scales of subjective indicators were transformed into the binary indicators for the sake of comparability across the domains. The first indicator 'household's capacity to make ends meet' equals 1 if the respondent chose responses 'easily and 'very easily' and 0 otherwise; this indicator is weighted by the proportion of households 
who chose responses 'with difficulty' and 'with great difficulty'. Overall, 3.5\% of households reported that they made ends meet easily or very easily, while over $45 \%$ of households reported that they made ends meet with difficulty or great difficulty. The second indicator, 'household's living conditions', equals 1 if the household reported 'good' and 'very good' living conditions, and 0 otherwise. This measure is weighted by the proportion of households who reported 'bad' and 'very bad' living conditions. Overall, 37.2\% of Russian households reported that their living conditions were good/very good, whereas $13.8 \%$ of households reported bad/very bad living conditions. Not surprisingly for public opinion questions like these, the majority of respondents chose the middle categories. As previously, different weights have been applied for twelve population subgroups (see Annex, Table 1). The two indicators were found to be weakly positively correlated (Spearman's rho equal to 0.095), but, as in the case of housing, they were still combined within one summary measure for further investigation.

\section{Combining the domain indices into an overall material well-being index}

After a set of domain indices had been obtained, these needed to be combined into an overall material well-being measure. In order to combine domain indices which are based on different measurement units, we transformed numerical scores into ranks (in ascending order). This put domains on the same metric and enabled us to combine income domain with other domain indices. The number of unique ranks varied across the domains due to different numbers of indicators. The highest number of unique ranks was in the income domain $(8,466)$. The durables domain had 1,054 unique ranks, the basic needs domain - 687 ranks, the housing domain - 243 ranks. The subjective well-being domain, which consisted of only two indicators, had the lowest number of unique ranks (27). These untransformed ranks were standardized by dividing each rank by the maximum rank of the domain and multiplying this by 100 . Thus all the domains have the same range, with 0 for the lowest level of material well-being and 100 for the highest level of material well-being.

As we explained above, in the process of constructing the domains it became clear that some domain indices are less reliable measures of the relevant aspects of material well-being than others. Firstly, the indicators within the housing domain are weakly correlated, which reflects the country specific situation in the housing market. Secondly, the subjective domain comprises only two indicators. We estimated the correlation coefficients between all pairs of 
domains (Table 7). The income domain was positively correlated with all other domains (including a strong association with basic needs, an average association with durables and housing and a weak association with subjective material well-being). The basic needs domain is strongly positively correlated with income and durables, and less strongly with subjective well-being, whereas correlation with housing is negligible. The housing domain is most strongly associated with income and subjective well-being. A reliability test shows that the highest level of internal consistency is achieved for a summary index comprising the three material well-being domains: income, basic needs and durables (Cronbach's alpha equals 0.710). This index will be further referred to as the basic material well-being index. If the housing domain is added to this index, its internal consistency decreases (Cronbach's alpha drops to 0.643 ). The reliability of a summary index, however, rises again if all five domains are combined (Cronbach's alpha is 0.658). We will refer to this measure as the extended material well-being index and will use it to see whether it adds anything to the analysis compared to the basic three-domain index.

Table 7 - Correlation among material well-being domains and reliability analysis for the aggregate material well-being index

\begin{tabular}{|l|ccccc|c|c|}
\hline & \multicolumn{3}{|c|}{ Correlation among well-being domains (Spearman's rho) } & \multicolumn{2}{c|}{ Reliability analysis } \\
\hline $\begin{array}{l}\text { Material well- } \\
\text { being domains: }\end{array}$ & Income & $\begin{array}{c}\text { Basic } \\
\text { needs }\end{array}$ & Durables & Housing & Subjective & $\begin{array}{c}\text { Corrected } \\
\text { item-total } \\
\text { correlatio } \\
\text { n }\end{array}$ & $\begin{array}{c}\text { Cronbach's } \\
\text { Alpha if } \\
\text { item } \\
\text { deleted }\end{array}$ \\
\hline (1) Income & 1.000 & 0.454 & 0.352 & 0.299 & 0.161 & 0.487 & 0.570 \\
(2) Basic needs & 0.454 & 1.000 & 0.537 & 0.085 & 0.261 & 0.486 & 0.570 \\
(3) Durables & 0.352 & 0.537 & 1.000 & 0.174 & 0.215 & 0.500 & 0.561 \\
(4) Housing & 0.299 & 0.085 & 0.174 & 1.000 & 0.251 & 0.279 & 0.672 \\
(5) Subjective & 0.161 & 0.261 & 0.215 & 0.251 & 1.000 & 0.321 & 0.643 \\
\hline $\begin{array}{l}\text { Cronbach's Alpha for welfare index including domains 1,2,3,4 and 5 } \\
\text { Cronbach's Alpha for welfare index including domains 1,2 and 3 }\end{array}$ & & & & & 0.658 \\
\hline
\end{tabular}

The approach in constructing the composite material well-being index was to conceptualize the various aspects of material well-being, as measured by each domain, as separate and 
distinct, though they may have cumulative effects for any household. For instance, this means that if a household has a high score in income and basic needs, its score on the summary material well-being index should be higher if compared to a household that has a high score in income and a low score in basic needs. At the same time, a high score in the income domain should not fully compensate for a low score in the basic needs domain. Weighting gives us control over these issues. For this purpose, the standardized domain scores were factor analyzed (using the Maximum Likelihood method) deriving weights for their combination. The analysis was run for indices that combined three, four and five material well-being domains. Respectively, the first factor explained 63.3, 49.9 and $43 \%$ of total variance and appeared to be a suitable summary measure across all three combinations of domains. The weights that were derived from the analysis ${ }^{20}$ are shown in Table 8.

In all three summary material well-being indices the highest contribution is provided by the basic needs domain; the durables domain has the second most important weight, followed by income. Consequently, our summary indices put the main emphasis on the non-monetary measures, rather than on current income. Compared to the basic needs domain the weight of the subjective well-being domain is 5 times as low, and the weight of the housing domain is 9 times as low, which is a consequence of a weaker correlation of these two domains with the rest, and their low reliability scores. This weighting provides a certain degree of cancellation of the impact of less reliable domains in the overall index. For example, in the unlikely, extreme case of a household ranking top on the income domain, but bottom on the housing domain, it will be ranked top in terms of overall material well-being. This would be in contrast to the $50^{\text {th }}$ percentile if the two domains were combined with equal weights.

Table 8 - Weight coefficients of material well-being domains (calculated on the basis of factor analysis, MLM)

\begin{tabular}{|c|c|c|c|}
\hline Well-being domains: & $\begin{array}{l}\text { Basic material } \\
\text { well-being index } \\
\text { WI-1 }\end{array}$ & $\begin{array}{l}\text { Basic material } \\
\text { well-being index } \\
\text { incl. housing } \\
\text { WI-2 }\end{array}$ & $\begin{array}{l}\text { Extended material } \\
\text { well-being index } \\
\text { WI-3 }\end{array}$ \\
\hline Income & 0.21 & 0.23 & 0.21 \\
\hline Basic needs & 0.49 & 0.42 & 0.38 \\
\hline Durables & 0.30 & 0.31 & 0.31 \\
\hline \multirow{3}{*}{$\begin{array}{l}\text { Housing } \\
\text { Subjective } \\
\end{array}$} & 1.00 & 0.04 & 0.04 \\
\hline & & 1.00 & 0.07 \\
\hline & & & 1.00 \\
\hline Total variance explained, \% & 63.306 & 49.984 & 43.188 \\
\hline
\end{tabular}


Finally, to produce the final material well-being measure the domain scores were summed for each household, using the weights in the table above. Thus, overall material well-being indices are:

WI-1 $=0.49 *$ basic needs $+0.30 *$ durables $+0.21 *$ income

WI-2 $=0.42 *$ basic needs $+0.31 *$ durables $+0.23 *$ income $+0.04 *$ housing

WI-3 $=0.38 *$ basic needs $+0.29 *$ durables $+0.21 *$ income $+0.04 *$ housing + $0.07 *$ subjective

The choice of one or another summary index depends on research objectives.

\section{Testing the validity of index}

In order to test the validity of the domain and composite indices we first looked at the relationship between the aggregate material well-being indices and a conventional income measure. Although income is positively correlated with other material well-being domains, it turns out that per capita income measure and the summary material well-being index rank households quite differently (Table 9). The most stable groups seem to be the first (the poorest) and the fifth (the richest) quintiles. However, only $57 \%$ of households falling into the fifth quintile by per capita income keep their place in this quintile by the summary material well-being measure. In the first quintile this figure is $48.7 \%$. In the rest of the distribution the mobility between quintiles is much higher.

Table 9 - Intersection of quintiles of per capita income and the summary material wellbeing index

\begin{tabular}{|c|c|c|c|c|c|c|}
\hline \multirow{2}{*}{ Quintiles of per capita income } & \multicolumn{5}{|c|}{ Quintiles of WI-1 } & \multirow{2}{*}{ Total } \\
\hline & 1 & 2 & 3 & 4 & 5 & \\
\hline 1 & $48.7 \%$ & $24.6 \%$ & $16.0 \%$ & $8.5 \%$ & $2.2 \%$ & $100.0 \%$ \\
\hline 2 & $31.8 \%$ & $28.9 \%$ & $21.9 \%$ & $14.1 \%$ & $3.4 \%$ & $100.0 \%$ \\
\hline 3 & $14.7 \%$ & $27.0 \%$ & $25.6 \%$ & $21.5 \%$ & $11.2 \%$ & $100.0 \%$ \\
\hline 4 & $4.4 \%$ & $14.9 \%$ & $23.5 \%$ & $31.0 \%$ & $26.3 \%$ & $100.0 \%$ \\
\hline 5 & $0.5 \%$ & $4.8 \%$ & $13.0 \%$ & $24.8 \%$ & $57.0 \%$ & $100.0 \%$ \\
\hline & $100.0 \%$ & $100.0 \%$ & $100.0 \%$ & $100.0 \%$ & $100.0 \%$ & $\mathrm{~N}=11117$ \\
\hline
\end{tabular}


Secondly, we have regressed the domain indices and the summary material well-being index on characteristics of household occupational class and demographic composition ${ }^{21}$. Occupational class is used in social stratification studies as an indicator of life-long earnings and life chances that are not properly captured by the more volatile current income (Breen 2005; Grusky and Weeden 2008). Family composition is another factor that has an impact on dimensions of well-being; household income varies across the family life-course (Rig and Sefton 2006). This association was documented for the first time by Rowntree (1901), who has pointed to the three stages in the life-course of workers in which they are more likely to fall into poverty (childhood, early middle life and old age).

The observed patterns confirm the presence of expected linear associations between material well-being and social class, as measured by the highest occupational status in the household (Figure 1). The summary material well-being index produces the clearest pattern of differentiation between the social classes, compared to all other well-being measures.

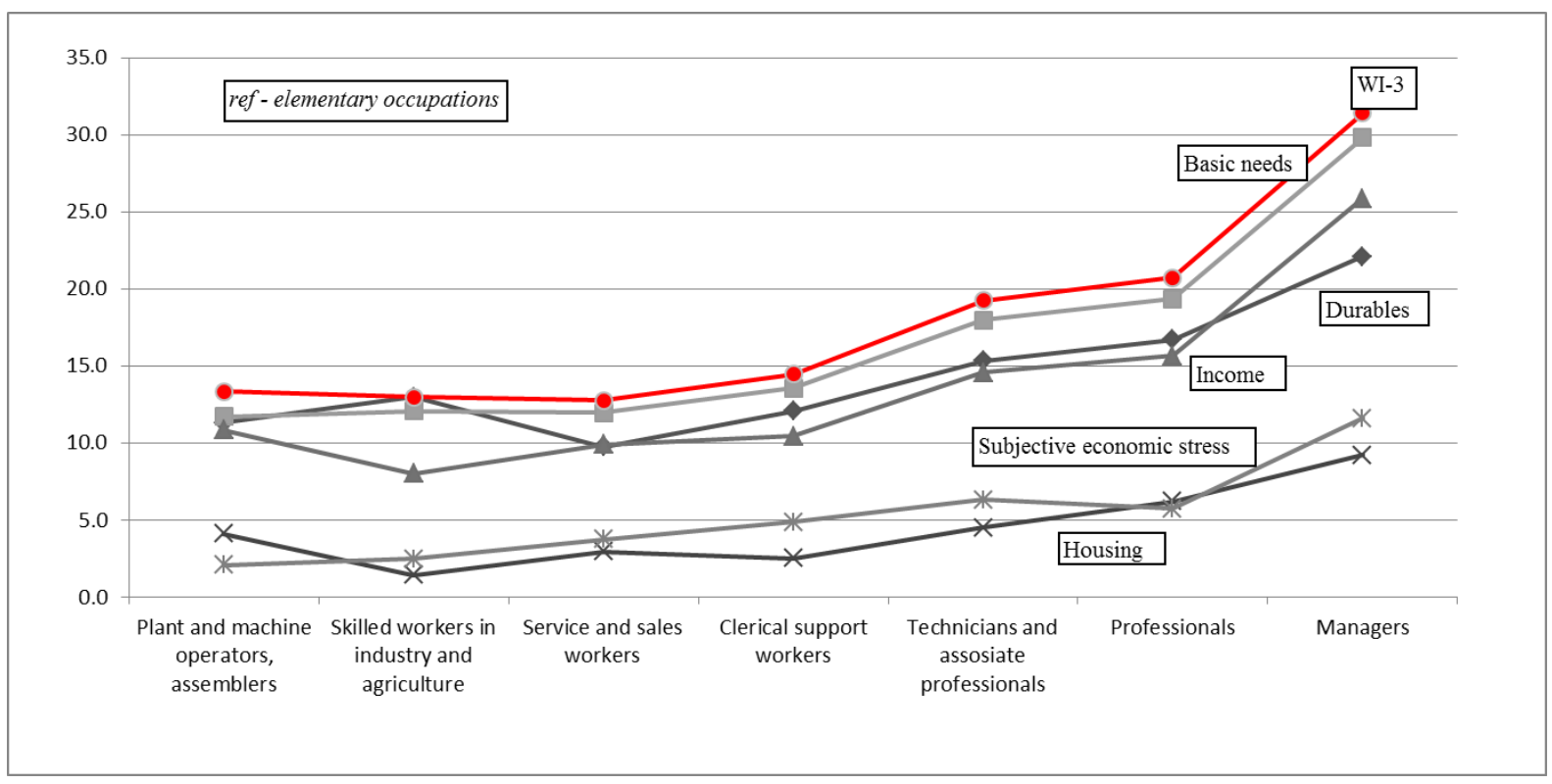

Figure 1 - Coefficients from an OLS regression of a summary index of material wellbeing on highest occupational status in the household*

* Controls: household size, demographic composition, highest level of education, number of employed, number of unemployed, number of disabled, type of settlement, region

The regression of a summary index on demographic composition, which reflects the lifecourse stage of the household, has contributed new information about the relative position of 
various demographic groups in Russia. The analysis on the basis of income measures typically shows that families with children are the most disadvantaged group in Russia (Ovcharova, Popova et al. 2007). Our analysis confirms that the presence of children greatly reduces material well-being of households in terms of income and housing. However, households without children have lower scores in terms of basic needs, durables and subjective material well-being (Figure 2). Thus, neither of the material well-being domains provides a full picture of living standards of demographic groups if used alone.

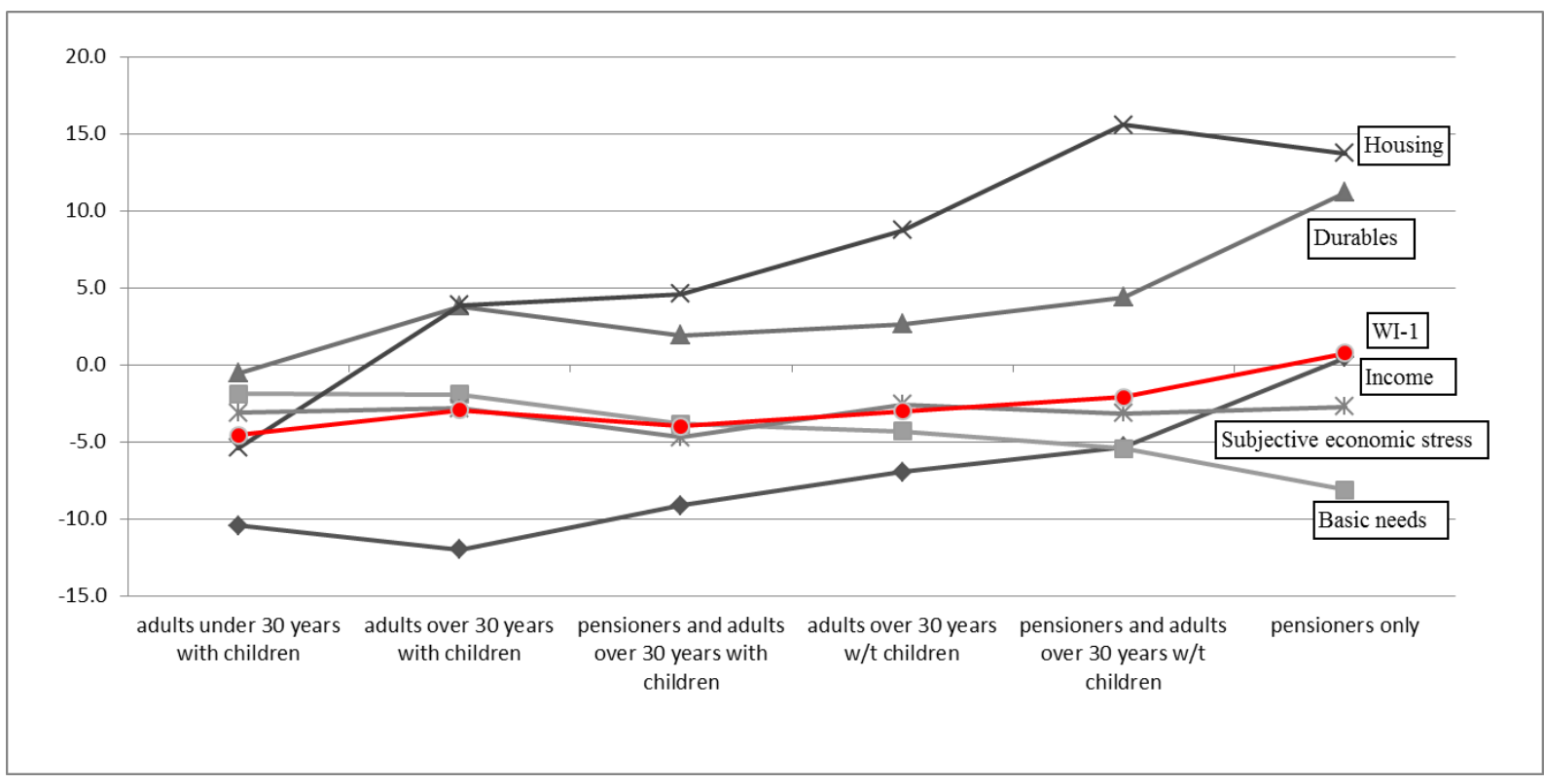

Figure 2 - Coefficients from an OLS regression of a summary index of material wellbeing on demographic composition of the household*

* Controls: household size, highest occupational status, highest level of education, number of employed, number of unemployed, number of disabled, type of settlement, region

As well as looking at the socio-demographic characteristics of households that influence material well-being it is also interesting to consider how various material well-being measures impact relevant outcomes. Here we focus on a measure of overall life satisfaction (question 'How are you satisfied with your life overall?' with a 5-item response scale ranging from 'quite satisfied' to 'not satisfied at all') which is often used as proxy for individual wellbeing (Schokkaert 2007). It would be expected at the population level that, other conditions being equal, respondents who can be defined as having low living standards would also be more likely to have lower scores on a life satisfaction measure, and vice versa. The use of this broad measure is also justified by the fact that our aggregate index already contains two material well-being focused measures within the subjective well-being domain. 
In Figure 3 we report the results of the OLS regressions with an overall life satisfaction as the dependent variable and domain indices and summary well-being indices as predictors. The resulting regression coefficients for any of our summary indices are twice as high as for income domain, 1.3 times as high as for basic needs, 1.8 times as high as for durables and 4.4 times as high as for housing and 1.4 times as high as for subjective well-being. Hence, the summary well-being measure adds significantly in the way of discriminatory capacity as far as overall life satisfaction is concerned.

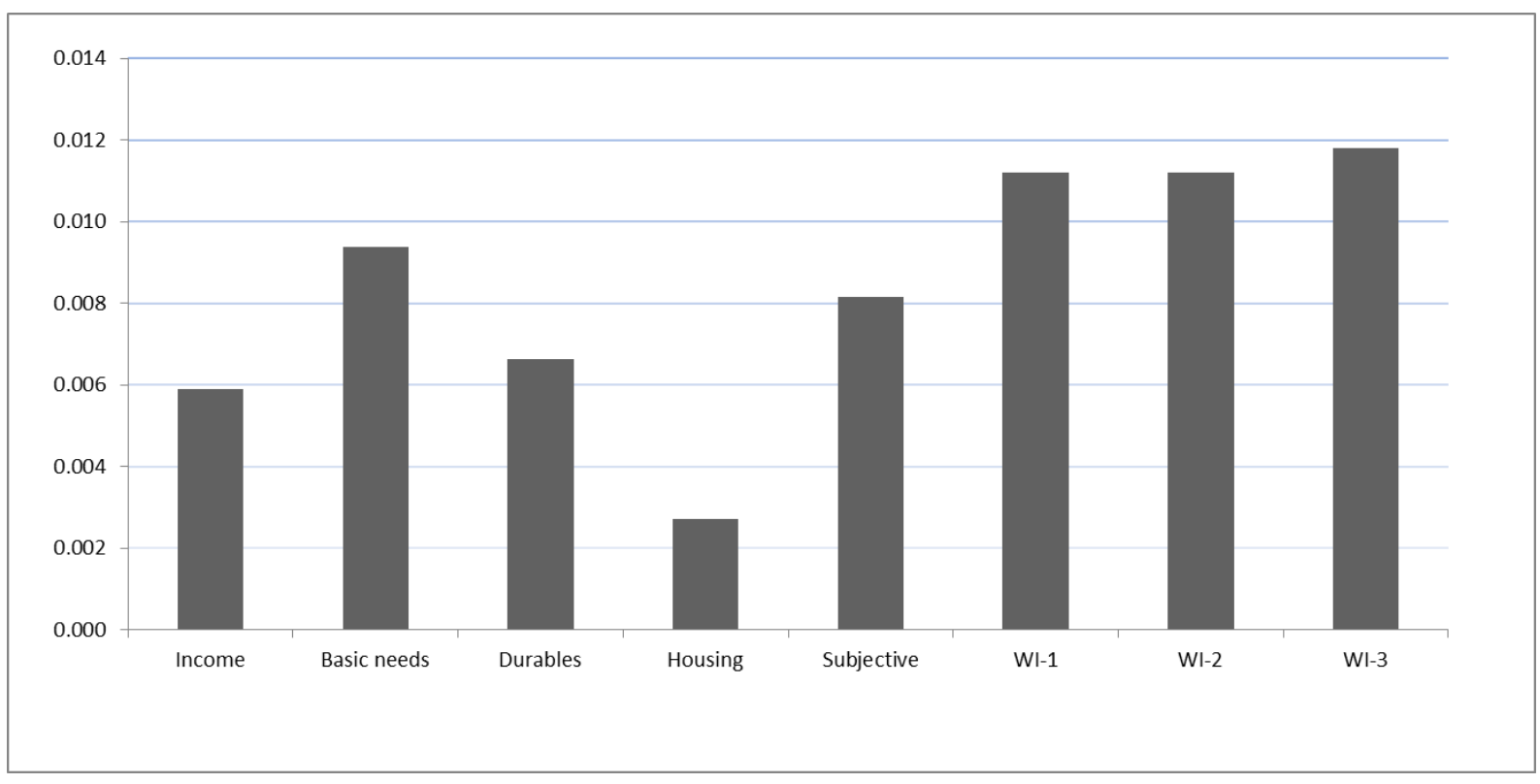

Figure 3 - Coefficients from an OLS regression of a life satisfaction on domain indices and summary indices of material well-being*

* Controls: household size, demographic composition, highest occupational status, highest level of education, number of employed, number of unemployed, number of disabled, type of settlement, region

\section{Conclusions}

This paper suggests an approach to the conceptualization of household material well-being as a composite of different dimensions or domains. These include income, the capacity to satisfy basic needs, durables, housing and a measure of subjective material well-being. Each dimension is measured independently using the best indicators available, to generate a score or domain index for each aspect of material well-being. The prevalence weighting within the 
separate domains enables us to account for disparity in resources and consumer preferences across the population subgroups. The final domain scores are then combined with explicit, empirically derived weights, to generate a summary material well-being index.

While recognizing income as a valuable measure of household material well-being in its own right, this paper argues that it should not be the only material well-being measure applied. The other dimensions of material well-being might contribute crucial further information about the relative position of various social and demographic groups on a stratification scale. The advantage of the proposed material well-being index is that it can be used both as a summary measure, but it can also be decomposed so that the performance within the separate well-being domains can be identified and the analysis of well-being extended. For example, the analysis for Russia showed that groups that typically appear the most disadvantaged in terms of current income (families with underage children) are doing better than others in terms of availability of durables and satisfaction of basic needs.

The domain indices and overall material well-being indices were validated by exploring their relationships to key socio-economic attributes, which were previously shown to be strongly associated with individual material well-being. The results showed that the summary indices of material well-being are characterized by greater differentiation in relation to such measures, as occupational class and life satisfaction. This allows us to conclude that our summary indices best capture the latent concept of material well-being. However, more elaborate regression analysis is required in order to confirm whether combinations of these different forms of material well-being are more than the sum of their parts: that is, they are not simply additive, but interact and may have more impact, if found in certain combinations.

Finally, it is important to note that although the proposed material well-being index is substantially linked to the GGS data for Russia, the methodological approach that we applied can be easily replicated in other GGS countries, and using other surveys that collect information on several aspects of material well-being. This is a subject for future research.

\section{Acknowledgements}

The authors would like to thank four anonymous referees for extensive and detailed comments. Support from the Basic Research Programme of the National Research University Higher School of Economics is gratefully acknowledged (TOR-36: The impact of changes in economic and social policies on consumer behavior of the population and fostering conditions for active aging, 2015). The views expressed are those of the authors. We are the only responsible for any errors as well. 


\section{References}

Alkire, S., P. Ballon, et al. (forthcoming 2015). Multidimensional poverty measurement and analysis: a counting approach. Oxford, Oxford University Press.

Bellani, L. (2013). "Multidimensional indices of deprivation: the introduction of reference groups weights." The Journal of Economic Inequality 11(4): 495-515.

Boarini, R. and M. Mira d'Ercole (2006). Measure of material deprivation in OECD countries. OECD Social Employment and Migration Working Papers No. 37. Paris, OECD.

Breen, R. (2005). Foundations of neo-Weberian class analysis. Approaches to class analysis. E. O. Wright. Cambridge, Cambridge University Press.

Cronbach, L. J. (1951). "Coefficient alpha and the internal structure of tests." Psychometrika 16: 297-334.

De Neubourg, C., M. De Milliano, et al. (2014). Lost (in) dimensions: Consolidating progress in multidimensional poverty research. Innocenti Working Paper No. 2014-04. Florence, UNICEF Office of Research.

Deaton, A. (1997). The analysis of household surveys: a microeconometric approach to development policy. Baltimore, MD, Johns Hopkins University Press.

Deaton, A. and S. Zaidi (2002). Guidelines for constructing consumption aggregates for welfare analysis. Washington, DC, World Bank.

Decancq, K. and M. A. Lugo (2013). "Weights in multidimensional indices of wellbeing: An overview." Econometric Reviews 32(1): 7-34.

Gimpelson, V. and R. Kapeliushnikov (2011). Labour market adjustment: is Russia different? IZA Discussion Paper No. 5588. Bonn, The Institute of Study of Labour.

Goedeme, T. and S. Rottiers (2011). "Poverty in the enlarged European Union. A discussion about definitions and reference groups." Sociology Compass 5(1): 77-91.

Gordon, D., L. Adelman, et al. (2000). Poverty and social exclusion in Britain. York, Joseph Rowntree Foundation.

Gorodnichenko, Y., K. Sabirianova Peter, et al. (2010). "Inequality and volatility moderation in Russia: evidence from micro-level panel data on consumption and income." Review of Economic Dynamics 13(1): 209-237.

Grusky, D. and K. Weeden (2008). Are there social classes? An empirical test of the sociologist's favorite concept. Social class: How does it work? A. Lareau and D. Conley. New York, Russell Sage Foundation.

Hallerod, B. (1994). A new approach to the direct consensual measurement of poverty. Social Policy Research Centre Discussion Papers No 50. Sydney, University of New South Wales.

Jacobs, R., P. Smith, et al. (2004). Measuring performance: An examination of composite performance indicators. CHE Technical Paper Series 29, Centre for Health Economics, University of York.

Klugman, J., Ed. (1997). Poverty in Russia: Public policy and private responses. Washington, D.C., IBRD/World bank.

Land, K. C., A. C. Michalos, et al., Eds. (2012). Handbook of social indicators and quality of life research. London, New York, Springer.

Levitas, R., C. Pantazis, et al. (2007). The multidimensional analysis of social exclusion. London, Department for Communities and Local Government (DCLG); also available online at http://webarchive.nationalarchives.gov.uk/+/http:/www.cabinetoffice.gov.uk/media/cabinetoffice/social _exclusion task force/assets/research/multidimensional.pdf

Mack, J. and S. Lansley (1985). Poor Britain. London, Allen \& Unwin.

Merton, R. K. and A. S. Rossi (1968). Contributions to the theory of reference group behavior. Social theory and social structure. R. K. Merton. New York, Free Press.

Nardo, M., M. Saisana, et al. (2005). Tools for composite indicators building EUR 21682 EN, Joint Research Centre, European Commission.

Nolan, B. and C. T. Whelan (1996). Resources, deprivation and the measurement of poverty. Oxford, Clarendon Press.

OECD (2008). Handbook on constructing composite indicators. Methodology and user guide. Paris, OECD.

OECD (2011). How's life? Measuring well-being. Paris, OECD.

OECD (2013). OECD guidelines on measuring subjective well-being, OECD.

Ovcharova, L., A. Pishniak, et al. (2006). Development of the methodology for defining the subsistence minimum given the new approaches to its calculation. Scientific report prepared for the Ministry of Health and Social Development Moscow Independent Institute for Social Policy.

Ovcharova, L. and D. Popova (2005). Child Poverty in Russia. Alarming Trends and Policy Options. Moscow, UNICEF. 
Ovcharova, L., D. Popova, et al. (2007). New measures supporting families with children: encouragement of the birthrate or improvement of the living standards? An analysis of the maternity and child support measures introduced in 2007 in the Russian Federation. Moscow, UNICEF.

Ovcharova, L. and E. D. Tesliuk (2006). Poverty and inequality in Russia: sensitivity of poverty and inequality statistics to alternative definitions of households welfare. Illustration using the NOBUS survey. Moscow, The World Bank.

Pantisano, F., M. Craglia, et al. (2014). New indicators of quality of life: A review of the literature, projects and applications. WP 2014 - Deviverable 201401, Citizen Science Observatory of new Indicators of Urban Substainability (project 1076), European Commission.

Popova, D. (2013). Country note: Russian Federation. Civil 20 Proposals for Strong, Sustainable, Balanced and Inclusive Growth. Moscow, UNDP.

Ravallion, M. (1994). Poverty comparisons. Chur, Switzerland, Harwood Academic Publishers GmbH.

Ravallion, M. (2012). "On multidimensional indices of poverty." Journal of Economic Inequality 9: 235-248.

Rig, J. and T. Sefton (2006). "Income dynamics and the life cycle." Journal of Social Policy 35(3): 411-435.

Rowntree, B. (1901). Poverty - a study of town life. London, Macmillan.

Schokkaert, E. (2007). "Capabilities and satisfaction with life." Journal of Human Development 8(5): 415-430.

Sen, A. K. (1976). "Poverty: an ordinal approach to measurement." Econometrica 44 (2): 219-231.

Sen, A. K. and J. E. Foster (1997). On economic inequality. Oxford, Oxford University Press.

Stiglitz, J. E., A. K. Sen, et al. (2009). Report by the Commission on the Measurement of Economic Performance and Social Progress. Paris, Available online from the Commission on the Measurement of Economic Performance and Social Progress: http://www.stiglitz-sen-fitoussi.fr/en/index.htm.

Townsend, P. (1979). Poverty in the United Kingdom : a survey of household resources and standards of living. Harmondsworth, Penguin.

UNDP (2011). National Human Development Report for the Russian Federation 2011. Modernisation and human development. Moscow, UNDP.

UNDP (2014). Human Development Report 2014. Sustaining human progress: Reducing vulnerabilities and building resilience. New York, NY, UNDP.

UNICEF (2011). The situation analysis of children in the Russian Federation: on the way to the equal opportunity society. Moscow, UNICEF.

Whelan, C. T. and B. Maitre (2009). "The 'Europeanisation' of Reference Groups. A reconsideration using EUSILC." European Societies 11(2): 283-309.

Whelan, C. T. and B. Maître (2010). "Welfare regime and social class variation in poverty and economic vulnerability in Europe: an analysis of EU-SILC "Journal of European Social policy 20: 316.

Whelan, C. T., B. Nolan, et al. (2014). "Multidimensional poverty measurement in Europe: an application of the Adjusted Headcount Approach." Journal of European Social Policy, 24 (2): 183-197.

Willitts, M. (2006). Measuring child poverty using material deprivation: possible approaches. Department for Work and Pensions Working Paper No 28. 


\section{Annex}

Table 1: Indicators and weights of indicators within the separate domains

\begin{tabular}{|c|c|c|c|c|c|c|c|c|c|c|c|c|c|}
\hline \multirow[b]{2}{*}{ Household groups: } & \multirow[b]{2}{*}{$\begin{array}{c}\text { on } \\
\text { average }\end{array}$} & \multicolumn{3}{|c|}{ regional centres: } & \multicolumn{3}{|c|}{ other cities: } & \multicolumn{3}{|c|}{ urban type settlements: } & \multicolumn{3}{|c|}{ rural area: } \\
\hline & & $\begin{array}{c}\text { working } \\
\text { age } \\
\text { people } \\
\text { with } \\
\text { children } \\
\text { under } 18 \\
\text { years }\end{array}$ & $\begin{array}{c}\text { working } \\
\text { age } \\
\text { people } \\
\text { w/t } \\
\text { children }\end{array}$ & $\begin{array}{c}\text { pensioners } \\
\text { w/t } \\
\text { children }\end{array}$ & $\begin{array}{c}\text { working } \\
\text { age } \\
\text { people } \\
\text { with } \\
\text { children } \\
\text { under } 18 \\
\text { years }\end{array}$ & $\begin{array}{c}\text { working } \\
\text { age } \\
\text { people } \\
\text { w/t } \\
\text { children }\end{array}$ & $\begin{array}{c}\text { pensioners } \\
\text { w/t } \\
\text { children }\end{array}$ & $\begin{array}{l}\text { working } \\
\text { age } \\
\text { people } \\
\text { with } \\
\text { children } \\
\text { under } 18 \\
\text { years }\end{array}$ & $\begin{array}{c}\text { working } \\
\text { age } \\
\text { people } \\
\text { w/t } \\
\text { children }\end{array}$ & $\begin{array}{c}\text { pensioners } \\
\text { w/t } \\
\text { children }\end{array}$ & $\begin{array}{c}\text { working } \\
\text { age } \\
\text { people } \\
\text { with } \\
\text { children } \\
\text { under } 18 \\
\text { years }\end{array}$ & $\begin{array}{l}\text { working } \\
\text { age } \\
\text { people } \\
\text { w/t } \\
\text { children }\end{array}$ & $\begin{array}{c}\text { pensioners } \\
\text { w/t } \\
\text { children }\end{array}$ \\
\hline \multirow[t]{2}{*}{$\mathrm{N}$} & 11062 & 1643 & 2122 & 820 & 1099 & 1273 & 647 & 256 & 249 & 145 & 1191 & 1021 & 596 \\
\hline & $100.0 \%$ & $14.9 \%$ & $19.2 \%$ & $7.4 \%$ & $9.9 \%$ & $11.5 \%$ & $5.8 \%$ & $2.3 \%$ & $2.3 \%$ & $1.3 \%$ & $10.8 \%$ & $9.2 \%$ & $5.4 \%$ \\
\hline \multicolumn{14}{|l|}{ Basic needs } \\
\hline keeping home adequately warm & $87.5 \%$ & $85.9 \%$ & $73.3 \%$ & $91.7 \%$ & $90.2 \%$ & $87.5 \%$ & $86.7 \%$ & $85.5 \%$ & $80.0 \%$ & $91.1 \%$ & $91.7 \%$ & $89.3 \%$ & $87.6 \%$ \\
\hline weight: cannot afford & $12.1 \%$ & $13.9 \%$ & $26.2 \%$ & $8.2 \%$ & $9.5 \%$ & $12.5 \%$ & $12.5 \%$ & $14.5 \%$ & $20.0 \%$ & $8.7 \%$ & $8.0 \%$ & $10.7 \%$ & $12.2 \%$ \\
\hline $\begin{array}{l}\text { buying new, rather than second-hand } \\
\text { clothes }\end{array}$ & $91.7 \%$ & $88.0 \%$ & $55.5 \%$ & $93.0 \%$ & $87.3 \%$ & $59.4 \%$ & $89.8 \%$ & $89.6 \%$ & $67.6 \%$ & $82.9 \%$ & $80.8 \%$ & $54.2 \%$ & $81.6 \%$ \\
\hline weight: cannot afford & $8.1 \%$ & $11.8 \%$ & $43.9 \%$ & $6.8 \%$ & $12.6 \%$ & $40.6 \%$ & $10.2 \%$ & $10.4 \%$ & $32.4 \%$ & $17.0 \%$ & $18.9 \%$ & $45.3 \%$ & $18.1 \%$ \\
\hline $\begin{array}{l}\text { eating meat, chicken or fish every } \\
\text { second day }\end{array}$ & $85.3 \%$ & $80.8 \%$ & $65.9 \%$ & $86.5 \%$ & $80.4 \%$ & $62.6 \%$ & $80.9 \%$ & $80.3 \%$ & $59.3 \%$ & $68.4 \%$ & $68.1 \%$ & $53.4 \%$ & $75.5 \%$ \\
\hline weight: cannot afford & $14.6 \%$ & $19.1 \%$ & $33.9 \%$ & $13.5 \%$ & $19.6 \%$ & $37.4 \%$ & $18.4 \%$ & $19.7 \%$ & $40.7 \%$ & $31.4 \%$ & $31.8 \%$ & $46.6 \%$ & $24.4 \%$ \\
\hline $\begin{array}{l}\text { paying for health care services, except } \\
\text { for expensive surgery, if necessary }\end{array}$ & $65.1 \%$ & $59.7 \%$ & $31.3 \%$ & $70.8 \%$ & $61.4 \%$ & $42.5 \%$ & $65.6 \%$ & $65.1 \%$ & $46.9 \%$ & $58.7 \%$ & $54.6 \%$ & $42.8 \%$ & $57.3 \%$ \\
\hline weight: cannot afford & $34.4 \%$ & $39.8 \%$ & $68.2 \%$ & $29.2 \%$ & $38.6 \%$ & $57.3 \%$ & $34.0 \%$ & $34.5 \%$ & $53.1 \%$ & $41.1 \%$ & $45.3 \%$ & $57.2 \%$ & $42.5 \%$ \\
\hline $\begin{array}{l}\text { having friends or family for a drink or } \\
\text { meal at least once a month }\end{array}$ & $62.8 \%$ & $57.1 \%$ & $29.8 \%$ & $61.7 \%$ & $51.4 \%$ & $22.3 \%$ & $64.1 \%$ & $58.2 \%$ & $42.8 \%$ & $42.7 \%$ & $40.5 \%$ & $21.3 \%$ & $48.7 \%$ \\
\hline weight: cannot afford & $37.0 \%$ & $42.7 \%$ & $70.0 \%$ & $38.2 \%$ & $48.5 \%$ & $77.7 \%$ & $35.9 \%$ & $41.8 \%$ & $57.2 \%$ & $57.2 \%$ & $59.4 \%$ & $78.5 \%$ & $51.2 \%$ \\
\hline replacing any worn-out furniture & $56.6 \%$ & $53.4 \%$ & $19.8 \%$ & $57.1 \%$ & $46.0 \%$ & $16.7 \%$ & $53.9 \%$ & $52.6 \%$ & $22.1 \%$ & $43.5 \%$ & $41.0 \%$ & $15.3 \%$ & $44.1 \%$ \\
\hline weight: cannot afford & $43.0 \%$ & $46.3 \%$ & $79.9 \%$ & $42.9 \%$ & $53.9 \%$ & $83.3 \%$ & $45.7 \%$ & $47.0 \%$ & $77.2 \%$ & $56.3 \%$ & $58.8 \%$ & $84.7 \%$ & $55.7 \%$ \\
\hline $\begin{array}{l}\text { paying for education of household } \\
\text { members if necessary }\end{array}$ & $51.9 \%$ & $39.9 \%$ & $5.1 \%$ & $51.0 \%$ & $37.9 \%$ & $7.1 \%$ & $47.3 \%$ & $35.3 \%$ & $6.9 \%$ & $40.6 \%$ & $32.8 \%$ & $5.4 \%$ & $35.3 \%$ \\
\hline weight: cannot afford & $47.2 \%$ & $59.2 \%$ & $92.2 \%$ & $48.5 \%$ & $61.5 \%$ & $90.9 \%$ & $52.0 \%$ & $64.3 \%$ & $91.0 \%$ & $59.2 \%$ & $67.0 \%$ & $94.1 \%$ & $63.9 \%$ \\
\hline $\begin{array}{l}\text { paying for a week's annual holiday } \\
\text { away from home }\end{array}$ & $41.1 \%$ & $43.3 \%$ & $16.8 \%$ & $35.9 \%$ & $31.0 \%$ & $8.2 \%$ & $36.3 \%$ & $33.3 \%$ & $20.0 \%$ & $17.5 \%$ & $15.2 \%$ & $6.4 \%$ & $28.7 \%$ \\
\hline weight: cannot afford & $58.4 \%$ & $56.2 \%$ & $82.7 \%$ & $64.1 \%$ & $69.0 \%$ & $91.7 \%$ & $63.7 \%$ & $65.9 \%$ & $80.0 \%$ & $82.5 \%$ & $84.7 \%$ & $93.3 \%$ & $71.0 \%$ \\
\hline
\end{tabular}




\begin{tabular}{|c|c|c|c|c|c|c|c|c|c|c|c|c|c|}
\hline \multirow[b]{2}{*}{ Household groups: } & \multirow[b]{2}{*}{$\begin{array}{c}\text { on } \\
\text { average }\end{array}$} & \multicolumn{3}{|c|}{ regional centres: } & \multicolumn{3}{|c|}{ other cities: } & \multicolumn{3}{|c|}{ urban type settlements: } & \multicolumn{3}{|c|}{ rural area: } \\
\hline & & $\begin{array}{c}\text { working } \\
\text { age } \\
\text { people } \\
\text { with } \\
\text { children } \\
\text { under } 18 \\
\text { years } \\
\end{array}$ & $\begin{array}{l}\text { working } \\
\text { age } \\
\text { people } \\
\text { w/t } \\
\text { children }\end{array}$ & $\begin{array}{c}\text { pensioners } \\
\text { w/t } \\
\text { children }\end{array}$ & $\begin{array}{c}\text { working } \\
\text { age } \\
\text { people } \\
\text { with } \\
\text { children } \\
\text { under } 18 \\
\text { years } \\
\end{array}$ & $\begin{array}{l}\text { working } \\
\text { age } \\
\text { people } \\
\text { w/t } \\
\text { children } \\
\end{array}$ & $\begin{array}{c}\text { pensioners } \\
\text { w/t } \\
\text { children } \\
\end{array}$ & $\begin{array}{c}\text { working } \\
\text { age } \\
\text { people } \\
\text { with } \\
\text { children } \\
\text { under } 18 \\
\text { years } \\
\end{array}$ & $\begin{array}{l}\text { working } \\
\text { age } \\
\text { people } \\
\text { w/t } \\
\text { children }\end{array}$ & $\begin{array}{c}\text { pensioners } \\
\text { w/t } \\
\text { children }\end{array}$ & $\begin{array}{c}\text { working } \\
\text { age } \\
\text { people } \\
\text { with } \\
\text { children } \\
\text { under } 18 \\
\text { years } \\
\end{array}$ & $\begin{array}{c}\text { working } \\
\text { age } \\
\text { people } \\
\text { w/t } \\
\text { children } \\
\end{array}$ & $\begin{array}{c}\text { pensioners } \\
\text { w/t } \\
\text { children }\end{array}$ \\
\hline $\mathrm{N}$ & $\begin{array}{c}11062 \\
100.0 \%\end{array}$ & $\begin{array}{c}1643 \\
14.9 \%\end{array}$ & $\begin{array}{c}2122 \\
19.2 \%\end{array}$ & $\begin{array}{l}820 \\
7.4 \%\end{array}$ & $\begin{array}{l}1099 \\
9.9 \%\end{array}$ & $\begin{array}{l}1273 \\
11.5 \%\end{array}$ & $\begin{array}{c}647 \\
5.8 \%\end{array}$ & $\begin{array}{c}256 \\
2.3 \%\end{array}$ & $\begin{array}{c}249 \\
2.3 \%\end{array}$ & $\begin{array}{l}145 \\
1.3 \%\end{array}$ & $\begin{array}{c}1191 \\
10.8 \%\end{array}$ & $\begin{array}{l}1021 \\
9.2 \%\end{array}$ & $\begin{array}{l}596 \\
5.4 \%\end{array}$ \\
\hline \multicolumn{14}{|l|}{ Durables } \\
\hline $\begin{array}{l}\text { a colour TV } \\
\text { weight: cannot afford }\end{array}$ & $\begin{array}{l}98.7 \% \\
0.7 \%\end{array}$ & $\begin{array}{l}96.3 \% \\
2.0 \%\end{array}$ & $\begin{array}{l}96.0 \% \\
2.7 \%\end{array}$ & $\begin{array}{l}99.2 \% \\
0.8 \%\end{array}$ & $\begin{array}{l}97.3 \% \\
1.8 \%\end{array}$ & $\begin{array}{l}94.1 \% \\
3.6 \%\end{array}$ & $\begin{array}{l}99.2 \% \\
0.8 \%\end{array}$ & $\begin{array}{l}97.6 \% \\
2.0 \%\end{array}$ & $\begin{array}{l}94.5 \% \\
4.1 \%\end{array}$ & $\begin{array}{l}97.3 \% \\
2.4 \%\end{array}$ & $\begin{array}{l}96.1 \% \\
3.2 \%\end{array}$ & $\begin{array}{l}88.4 \% \\
7.9 \%\end{array}$ & $\begin{array}{l}96.6 \% \\
2.3 \%\end{array}$ \\
\hline $\begin{array}{l}\text { a washing machine } \\
\text { weight: } \text { cannot afford }\end{array}$ & $\begin{array}{l}89.6 \% \\
7.2 \%\end{array}$ & $\begin{array}{l}81.9 \% \\
11.3 \%\end{array}$ & $\begin{array}{l}74.4 \% \\
14.8 \%\end{array}$ & $\begin{array}{l}93.1 \% \\
5.3 \%\end{array}$ & $\begin{array}{l}90.3 \% \\
6.8 \%\end{array}$ & $\begin{array}{l}80.5 \% \\
13.0 \%\end{array}$ & $\begin{array}{l}91.0 \% \\
8.6 \%\end{array}$ & $\begin{array}{l}88.4 \% \\
10.8 \%\end{array}$ & $\begin{array}{l}85.5 \% \\
11.7 \%\end{array}$ & $\begin{array}{l}86.7 \% \\
10.2 \%\end{array}$ & $\begin{array}{l}86.7 \% \\
9.7 \%\end{array}$ & $\begin{array}{l}74.5 \% \\
14.1 \%\end{array}$ & $\begin{array}{l}85.4 \% \\
9.7 \%\end{array}$ \\
\hline $\begin{array}{l}\text { a telephone (fixed or mobile) } \\
\text { weight: cannot afford }\end{array}$ & $\begin{array}{l}94.5 \% \\
3.5 \%\end{array}$ & $\begin{array}{l}93.3 \% \\
4.2 \%\end{array}$ & $\begin{array}{l}90.6 \% \\
4.8 \%\end{array}$ & $\begin{array}{l}95.0 \% \\
2.8 \%\end{array}$ & $\begin{array}{l}89.3 \% \\
6.1 \%\end{array}$ & $\begin{array}{l}72.5 \% \\
12.8 \%\end{array}$ & $\begin{array}{l}91.8 \% \\
5.1 \%\end{array}$ & $\begin{array}{l}88.0 \% \\
7.2 \%\end{array}$ & $\begin{array}{l}69.0 \% \\
14.5 \%\end{array}$ & $\begin{array}{l}76.1 \% \\
17.5 \%\end{array}$ & $\begin{array}{l}73.5 \% \\
16.0 \%\end{array}$ & $\begin{array}{l}49.5 \% \\
21.8 \%\end{array}$ & $\begin{array}{l}85.2 \% \\
8.4 \%\end{array}$ \\
\hline $\begin{array}{l}\text { a video recorder or DVD player } \\
\text { weight: cannot afford }\end{array}$ & $\begin{array}{l}86.1 \% \\
6.9 \%\end{array}$ & $\begin{array}{l}72.7 \% \\
11.6 \%\end{array}$ & $\begin{array}{l}24.9 \% \\
14.9 \%\end{array}$ & $\begin{array}{l}87.7 \% \\
8.5 \%\end{array}$ & $\begin{array}{l}72.4 \% \\
13.4 \%\end{array}$ & $\begin{array}{l}21.8 \% \\
19.3 \%\end{array}$ & $\begin{array}{l}89.8 \% \\
5.9 \%\end{array}$ & $\begin{array}{l}77.1 \% \\
11.2 \%\end{array}$ & $\begin{array}{l}31.0 \% \\
16.6 \%\end{array}$ & $\begin{array}{l}79.3 \% \\
16.5 \%\end{array}$ & $\begin{array}{l}64.5 \% \\
19.9 \%\end{array}$ & $\begin{array}{l}11.2 \% \\
22.5 \%\end{array}$ & $\begin{array}{l}66.2 \% \\
13.3 \%\end{array}$ \\
\hline $\begin{array}{l}\text { a microwave } \\
\text { weight: cannot afford }\end{array}$ & $\begin{array}{l}58.9 \% \\
21.5 \%\end{array}$ & $\begin{array}{l}48.2 \% \\
22.8 \%\end{array}$ & $\begin{array}{l}20.1 \% \\
25.0 \%\end{array}$ & $\begin{array}{l}56.7 \% \\
26.1 \%\end{array}$ & $\begin{array}{l}42.3 \% \\
29.9 \%\end{array}$ & $\begin{array}{l}13.4 \% \\
31.7 \%\end{array}$ & $\begin{array}{l}50.0 \% \\
38.3 \%\end{array}$ & $\begin{array}{l}44.2 \% \\
30.5 \%\end{array}$ & $\begin{array}{l}19.3 \% \\
28.3 \%\end{array}$ & $\begin{array}{l}31.5 \% \\
51.6 \%\end{array}$ & $\begin{array}{l}25.1 \% \\
46.9 \%\end{array}$ & $\begin{array}{l}6.0 \% \\
33.4 \%\end{array}$ & $\begin{array}{l}39.2 \% \\
30.9 \%\end{array}$ \\
\hline $\begin{array}{l}\text { a car or a van available for private use } \\
\text { weight: cannot afford }\end{array}$ & $\begin{array}{l}40.8 \% \\
36.3 \%\end{array}$ & $\begin{array}{l}31.0 \% \\
36.3 \%\end{array}$ & $\begin{array}{l}10.7 \% \\
15.7 \%\end{array}$ & $\begin{array}{l}46.5 \% \\
30.4 \%\end{array}$ & $\begin{array}{l}36.7 \% \\
32.2 \%\end{array}$ & $\begin{array}{l}8.0 \% \\
19.8 \%\end{array}$ & $\begin{array}{l}49.2 \% \\
36.7 \%\end{array}$ & $\begin{array}{l}43.0 \% \\
34.9 \%\end{array}$ & $\begin{array}{l}16.6 \% \\
13.8 \%\end{array}$ & $\begin{array}{l}41.7 \% \\
41.2 \%\end{array}$ & $\begin{array}{l}41.4 \% \\
34.0 \%\end{array}$ & $\begin{array}{l}11.9 \% \\
20.3 \%\end{array}$ & $\begin{array}{l}33.4 \% \\
31.9 \%\end{array}$ \\
\hline $\begin{array}{l}\text { a home computer, laptop } \\
\text { weight: cannot afford }\end{array}$ & $\begin{array}{l}57.6 \% \\
27.6 \% \\
\end{array}$ & $\begin{array}{l}47.8 \% \\
23.1 \% \\
\end{array}$ & $\begin{array}{l}5.9 \% \\
14.5 \% \\
\end{array}$ & $\begin{array}{l}52.0 \% \\
31.5 \% \\
\end{array}$ & $\begin{array}{l}34.2 \% \\
31.1 \% \\
\end{array}$ & $\begin{array}{l}1.5 \% \\
14.4 \% \\
\end{array}$ & $\begin{array}{l}42.6 \% \\
43.4 \% \\
\end{array}$ & $\begin{array}{l}32.1 \% \\
31.3 \% \\
\end{array}$ & $\begin{array}{l}6.9 \% \\
13.1 \% \\
\end{array}$ & $\begin{array}{l}23.9 \% \\
60.0 \% \\
\end{array}$ & $\begin{array}{l}14.6 \% \\
44.9 \% \\
\end{array}$ & $\begin{array}{l}0.8 \% \\
16.1 \% \\
\end{array}$ & $\begin{array}{l}33.1 \% \\
30.5 \% \\
\end{array}$ \\
\hline $\begin{array}{l}\text { a second home (e.g. house, flat, winter } \\
\text { cottage) } \\
\text { weight: } \text { cannot afford }\end{array}$ & $\begin{array}{l}23.1 \% \\
41.7 \% \\
\end{array}$ & $\begin{array}{l}25.1 \% \\
34.2 \% \\
\end{array}$ & $\begin{array}{l}20.5 \% \\
18.5 \% \\
\end{array}$ & $\begin{array}{l}17.4 \% \\
28.9 \% \\
\end{array}$ & $\begin{array}{l}20.8 \% \\
28.2 \% \\
\end{array}$ & $\begin{array}{l}16.8 \% \\
14.8 \% \\
\end{array}$ & $\begin{array}{l}17.6 \% \\
48.0 \% \\
\end{array}$ & $\begin{array}{l}17.3 \% \\
34.9 \% \\
\end{array}$ & $\begin{array}{l}4.1 \% \\
10.3 \% \\
\end{array}$ & $\begin{array}{l}2.2 \% \\
42.1 \% \\
\end{array}$ & $\begin{array}{l}3.0 \% \\
34.4 \% \\
\end{array}$ & $\begin{array}{l}1.5 \% \\
15.8 \% \\
\end{array}$ & $\begin{array}{l}16.3 \% \\
31.7 \% \\
\end{array}$ \\
\hline $\begin{array}{l}\text { a second home (e.g. a summer cottage) } \\
\text { weight: cannot afford }\end{array}$ & $\begin{array}{l}11.3 \% \\
58.8 \%\end{array}$ & $\begin{array}{l}9.4 \% \\
49.0 \%\end{array}$ & $\begin{array}{l}2.7 \% \\
21.3 \%\end{array}$ & $\begin{array}{l}8.8 \% \\
41.0 \%\end{array}$ & $\begin{array}{l}8.4 \% \\
40.6 \%\end{array}$ & $\begin{array}{l}3.7 \% \\
20.6 \%\end{array}$ & $\begin{array}{l}17.2 \% \\
57.0 \%\end{array}$ & $\begin{array}{l}14.1 \% \\
44.6 \%\end{array}$ & $\begin{array}{l}10.3 \% \\
15.2 \%\end{array}$ & $\begin{array}{l}6.0 \% \\
53.1 \%\end{array}$ & $\begin{array}{l}4.8 \% \\
43.6 \%\end{array}$ & $\begin{array}{l}2.5 \% \\
17.8 \%\end{array}$ & $\begin{array}{l}7.8 \% \\
42.9 \%\end{array}$ \\
\hline $\begin{array}{l}\text { a second car } \\
\text { weight: cannot afford }\end{array}$ & $\begin{array}{l}5.6 \% \\
35.1 \%\end{array}$ & $\begin{array}{l}5.3 \% \\
30.6 \%\end{array}$ & $\begin{array}{l}0.5 \% \\
12.4 \%\end{array}$ & $\begin{array}{l}5.6 \% \\
30.4 \%\end{array}$ & $\begin{array}{l}3.0 \% \\
29.5 \%\end{array}$ & $\begin{array}{l}0.6 \% \\
13.6 \%\end{array}$ & $\begin{array}{l}12.1 \% \\
41.4 \%\end{array}$ & $\begin{array}{l}8.0 \% \\
33.3 \%\end{array}$ & $\begin{array}{l}2.1 \% \\
6.9 \%\end{array}$ & $\begin{array}{l}6.1 \% \\
43.4 \%\end{array}$ & $\begin{array}{l}5.4 \% \\
35.7 \%\end{array}$ & $\begin{array}{l}0.3 \% \\
15.6 \%\end{array}$ & $\begin{array}{l}4.5 \% \\
29.8 \%\end{array}$ \\
\hline $\begin{array}{l}\text { a dishwasher } \\
\text { weight: cannot afford }\end{array}$ & $\begin{array}{l}2.5 \% \\
28.8 \%\end{array}$ & $\begin{array}{l}1.4 \% \\
25.2 \%\end{array}$ & $\begin{array}{l}0.6 \% \\
15.9 \%\end{array}$ & $\begin{array}{l}1.2 \% \\
31.1 \%\end{array}$ & $\begin{array}{l}0.9 \% \\
28.4 \%\end{array}$ & $\begin{array}{l}0.2 \% \\
17.0 \%\end{array}$ & $\begin{array}{l}3.1 \% \\
41.8 \%\end{array}$ & $\begin{array}{l}1.6 \% \\
30.1 \%\end{array}$ & $\begin{array}{l}0.7 \% \\
11.7 \%\end{array}$ & $\begin{array}{l}0.7 \% \\
48.9 \%\end{array}$ & $\begin{array}{l}0.8 \% \\
41.3 \%\end{array}$ & $\begin{array}{l}0.3 \% \\
19.5 \%\end{array}$ & $\begin{array}{l}1.2 \% \\
29.6 \%\end{array}$ \\
\hline
\end{tabular}




\begin{tabular}{|c|c|c|c|c|c|c|c|c|c|c|c|c|c|}
\hline \multirow[b]{2}{*}{ Household groups: } & \multirow[b]{2}{*}{$\begin{array}{c}\text { on } \\
\text { average }\end{array}$} & \multicolumn{3}{|c|}{ regional centres: } & \multicolumn{3}{|c|}{ other cities: } & \multicolumn{3}{|c|}{ urban type settlements: } & \multicolumn{3}{|c|}{ rural area: } \\
\hline & & $\begin{array}{l}\text { working } \\
\text { age } \\
\text { people } \\
\text { with } \\
\text { children } \\
\text { under } 18 \\
\text { years } \\
\end{array}$ & $\begin{array}{l}\text { working } \\
\text { age } \\
\text { people } \\
\text { w/t } \\
\text { children } \\
\end{array}$ & $\begin{array}{c}\text { pensioners } \\
\text { w/t } \\
\text { children } \\
\end{array}$ & $\begin{array}{c}\text { working } \\
\text { age } \\
\text { people } \\
\text { with } \\
\text { children } \\
\text { under } 18 \\
\text { years } \\
\end{array}$ & $\begin{array}{l}\text { working } \\
\text { age } \\
\text { people } \\
\text { w/t } \\
\text { children } \\
\end{array}$ & $\begin{array}{c}\text { pensioners } \\
\text { w/t } \\
\text { children } \\
\end{array}$ & $\begin{array}{c}\text { working } \\
\text { age } \\
\text { people } \\
\text { with } \\
\text { children } \\
\text { under } 18 \\
\text { years } \\
\end{array}$ & $\begin{array}{l}\text { working } \\
\text { age } \\
\text { people } \\
\text { w/t } \\
\text { children } \\
\end{array}$ & $\begin{array}{c}\text { pensioners } \\
\text { w/t } \\
\text { children } \\
\end{array}$ & $\begin{array}{c}\text { working } \\
\text { age } \\
\text { people } \\
\text { with } \\
\text { children } \\
\text { under } 18 \\
\text { years } \\
\end{array}$ & $\begin{array}{l}\text { working } \\
\text { age } \\
\text { people } \\
\text { w/t } \\
\text { children } \\
\end{array}$ & $\begin{array}{c}\text { pensioners } \\
\text { w/t } \\
\text { children }\end{array}$ \\
\hline \multirow[t]{2}{*}{$\mathrm{N}$} & 11062 & 1643 & 2122 & 820 & 1099 & 1273 & 647 & 256 & 249 & 145 & 1191 & 1021 & 596 \\
\hline & $100.0 \%$ & $14.9 \%$ & $19.2 \%$ & $7.4 \%$ & $9.9 \%$ & $11.5 \%$ & $5.8 \%$ & $2.3 \%$ & $2.3 \%$ & $1.3 \%$ & $10.8 \%$ & $9.2 \%$ & $5.4 \%$ \\
\hline \multicolumn{14}{|l|}{ Housing } \\
\hline $\begin{array}{l}\text { separate accommodation (flat, } \\
\text { house/part of a house) }\end{array}$ & $92.1 \%$ & $83.9 \%$ & $83.8 \%$ & $94.3 \%$ & $94.3 \%$ & $95.6 \%$ & $98.3 \%$ & $95.7 \%$ & $98.4 \%$ & $98.6 \%$ & $97.2 \%$ & $97.4 \%$ & $97.3 \%$ \\
\hline weight: not separate accommodation & $7.9 \%$ & $16.1 \%$ & $16.2 \%$ & $5.7 \%$ & $5.7 \%$ & $4.4 \%$ & $1.7 \%$ & $4.3 \%$ & $1.6 \%$ & $1.4 \%$ & $2.8 \%$ & $2.6 \%$ & $2.7 \%$ \\
\hline own accommodation & $73.8 \%$ & $60.4 \%$ & $62.0 \%$ & $84.5 \%$ & $74.0 \%$ & $77.1 \%$ & $90.9 \%$ & $80.9 \%$ & $82.3 \%$ & $89.7 \%$ & $73.6 \%$ & $81.1 \%$ & $89.9 \%$ \\
\hline weight: tenants paying market rent & $3.1 \%$ & $4.6 \%$ & $5.0 \%$ & $0.1 \%$ & $5.1 \%$ & $3.1 \%$ & $0.2 \%$ & $3.9 \%$ & $2.0 \%$ & $0.0 \%$ & $3.1 \%$ & $1.3 \%$ & $0.3 \%$ \\
\hline an adequate number of rooms & $77.1 \%$ & $44.7 \%$ & $79.9 \%$ & $99.1 \%$ & $59.1 \%$ & $87.9 \%$ & $99.5 \%$ & $67.6 \%$ & $90.4 \%$ & $100.0 \%$ & $68.9 \%$ & $90.1 \%$ & $98.3 \%$ \\
\hline weight: low number of rooms & $22.9 \%$ & $55.3 \%$ & $20.1 \%$ & $0.9 \%$ & $40.9 \%$ & $12.1 \%$ & $0.5 \%$ & $32.4 \%$ & $9.6 \%$ & $0.0 \%$ & $31.1 \%$ & $9.9 \%$ & $1.7 \%$ \\
\hline $\begin{array}{l}\text { weight: accommodation is not } \\
\text { equipped with all necessary utilities }\end{array}$ & $40.8 \%$ & $19.8 \%$ & $20.2 \%$ & $18.7 \%$ & $31.1 \%$ & $27.7 \%$ & $40.2 \%$ & $41.4 \%$ & $42.2 \%$ & $56.6 \%$ & $83.5 \%$ & $82.7 \%$ & $87.8 \%$ \\
\hline $\begin{array}{l}\text { living area equal or above the social } \\
\text { standard }\end{array}$ & $46.9 \%$ & $16.1 \%$ & $48.0 \%$ & $74.0 \%$ & $22.0 \%$ & $56.6 \%$ & $73.9 \%$ & $33.2 \%$ & $67.5 \%$ & $76.6 \%$ & $28.7 \%$ & $65.8 \%$ & $79.5 \%$ \\
\hline $\begin{array}{l}\text { weight: living area below the social } \\
\text { standard }\end{array}$ & $53.1 \%$ & $83.9 \%$ & $52.0 \%$ & $26.0 \%$ & $78.0 \%$ & $43.4 \%$ & $26.1 \%$ & $66.8 \%$ & $32.5 \%$ & $23.4 \%$ & $71.3 \%$ & $34.2 \%$ & $20.5 \%$ \\
\hline \multicolumn{14}{|l|}{ Subjective material well-being } \\
\hline good living conditions & $30.2 \%$ & $36.4 \%$ & $44.6 \%$ & $41.1 \%$ & $44.5 \%$ & $41.0 \%$ & $44.5 \%$ & $47.0 \%$ & $44.8 \%$ & $32.6 \%$ & $34.8 \%$ & $26.0 \%$ & $37.2 \%$ \\
\hline weight: bad living conditions & $22.1 \%$ & $15.9 \%$ & $10.9 \%$ & $11.8 \%$ & $9.4 \%$ & $7.7 \%$ & $13.7 \%$ & $6.8 \%$ & $9.0 \%$ & $13.9 \%$ & $11.3 \%$ & $16.3 \%$ & $13.8 \%$ \\
\hline make ends meet easily & $3.8 \%$ & $5.7 \%$ & $4.0 \%$ & $4.0 \%$ & $3.3 \%$ & $3.1 \%$ & $2.3 \%$ & $2.8 \%$ & $4.8 \%$ & $1.9 \%$ & $1.7 \%$ & $1.7 \%$ & $3.5 \%$ \\
\hline weight: make ends meet with difficulty & $37.8 \%$ & $37.1 \%$ & $52.1 \%$ & $38.5 \%$ & $38.8 \%$ & $57.3 \%$ & $43.8 \%$ & $34.5 \%$ & $45.5 \%$ & $56.0 \%$ & $55.4 \%$ & $57.6 \%$ & $44.9 \%$ \\
\hline
\end{tabular}


1 GGS is a part of the international research programme of UNECE. More details can be found at: http://www.unece.org/pau/ggp/Welcome.html.

${ }^{2}$ This is something different from the hidden or the illegal economies. The latter comprise the activities related to tax fraud or tax evasion or illegal activities. The non-observed economy also comprises activities that have nothing to do with criminality or tax evasion, but that still remain unobserved because the traditional survey tools are not perfect and business registers are not always complete and up-to-date.

${ }^{3}$ Persons living in institutional households (children's homes, social care institutions, convents) are excluded. In geographical terms the sample covers 32 (out of 83) regions and is not representative at the regional level, which is the main limitation of the survey. On average the household response rate exceeds $80 \%$, but it is lower in Moscow and St-Petersburg (less than 60\%).

${ }^{4}$ For more information about RLMS-HSE survey see: http://www.hse.ru/en/rlms/

${ }^{5}$ GGS-2007 was conducted in April-September 2007 by the Independent Institute for Social Policy with financial support from the Pension Fund of the Russian Federation, UNFPA, Sberbank of Russia, Children's Foundation 'Victoria' and Ford Foundation.

${ }^{6}$ Because of the conceptually different nature of our indicators we chose not to rely on statistical methods, such as Factor analysis (FA) or Principal Component Analysis (PCA), to define our dimensions for us. The OECD handbook on composite indicators stresses that PCA and FA should be used with caution, as they may "identify dimensions that do not necessarily help to reveal the clustering structure in the data and may actually mask the taxonomic information" (OECD 2008, p. 26). Generally speaking, PA and PCA, being non-probabilistic methods, are very sensitive to slight alterations in the structure of data; and there is no 'objective' procedure for judging the validity of their results.

${ }^{7}$ For example, Eurostat treats 'the presence of mortgage or rent payments, utility bills, hire purchase instalments or other loan payments' in the household as a component of the EU material deprivation index.

${ }^{8}$ In our case the options for the denominator are as follows: the proportion of households who have nominated an item as a necessity; the proportion of households who report that they do not have an item or who report an enforced lack of an item. All these options are essentially variations of the prevalence weighting approach. The first option which relies on judgments about the relative weights of items made by respondents themselves should be a preferred option, but these data are not available in our survey, and in fact are rarely collected in general purpose large-scale surveys. In the absence of the public opinion data, we relied on the information about actual consumption choices, and among the two options available we opted for accounting for the 'enforced lack' as it captures the preferences of individuals.

${ }^{9}$ The sample yields functional values for a segment as small as $1.5 \%$ of the total population. In this case the sample error is $20 \%$ at $95 \%$ confidence level.

${ }^{10}$ It is noteworthy, the use of reference group-level weights generally leads to the reduction in inequalities between various population subgroups, because in this case the position of each household is estimated relative to the position of its reference groups, rather than relative to the average national standard. The more disadvantage groups are likely to have lower living standards. For example, if the national-level prevalence weights were applied in the durables domain instead of the reference group-level weights, the gap in average well-being scores between households from large cities and the rural area would be 1.2 times as high as it appears to be under the current weighting scheme, while the gap between households with children and households of pensioners would be 1.8 times as high as under the current scheme. This issues deserve further consideration in future research.

11 The natural logarithm of per capita income was regressed on a set of household characteristics, including household composition, education level, labour market status, presence of various sources of income and dummies for the region and the type of settlement to account for the unobserved parameters of the local market.

${ }^{12}$ The minimum consumer basket - referred to as the Minimum Subsistence Level (MSL) - is the official poverty threshold in Russia. The value of MSL is calculated separately for three socio-demographic groups - children up to 16 years, persons of active working age (men of 16-59 years and women of 16-54 years) and persons of pension age (men of 60+ years and women of 55+ years). It is set quarterly in all 83 regions, and for Russia as a whole.

${ }^{13}$ We did not apply any equivalence scale, following the standard practice of the national statistics agency which uses per capita incomes. This is unlikely to alter our results significantly because the structure of household consumption in Russia differs from that in a mature market economy. The share of spending on rent and utilities is substantially lower, while the share of spending on food is higher, resulting in lower economies. Previous studies for Russia indicated that the elasticity coefficient based on the analysis of Engel curves (food shares) was equal to 0.9 in early 1990s (See: Klugman, J., Ed. (1997). Poverty in Russia: Public policy and private responses. Washington, 
D.C., IBRD/World bank.). This has declined to 0.78 by 2003 (see: Ovcharova, L., A. Pishniak, et al. (2006). Development of the methodology for defining the subsistence minimum given the new approaches to its calculation. Scientific report prepared for the Ministry of Health and Social Development Moscow Independent Institute for Social Policy.). More recent estimates were not available at the time of writing.

${ }^{14}$ We have considered another indicator of income security which could be relevant for post-transition countries like Russia - the share of income from/consumption of home produced food in total household income/consumption. Home production of food was an important source of consumption in the 1990s, yet the share of this source in total income/consumption in Russia has substantially decreased since the beginning of 2000s. According to RLMS-HSE for 2008 the share of income from 'in-kind home production and informal sector' in total household income was $3.9 \%$ on average, while the share of households that had this source of income was $44.3 \%$, with very little variation across income quintiles. The share of home produced food consumption in total household consumption was 3.4\%, with little variation by quintile (see: http://www.hse.ru/data/2015/10/09/1077435180/Vestnik\%20RLMSHSE_2015.pdf). This can be interpreted as follows. Quite a large number of Russian households have summer cottages and small land allotments where they do some gardening over the summer, but it does not have a substantial impact on their material well-being, maybe apart from the psychological effect, as home grown food is perceived as a better quality 'organic' food. There is a category of rural households that rely heavily on home production but this group is small and is not identifiable in GGS because consumption data was not collected.

${ }^{15}$ It does not matter whether an item is owned, rented, or otherwise provided for household use.

${ }^{16}$ For instance, according to the all-Russian household survey conducted in 2003, the market rent was 5 times as high as the sum of the bills paid by homeowners and tenants renting from the state or municipality (see: Ovcharova, L. and E. D. Tesliuk (2006). Poverty and inequality in Russia: sensitivity of poverty and inequality statistics to alternative definitions of households welfare. Illustration using the NOBUS survey. Moscow, The World Bank.).

${ }^{17}$ It is noteworthy, although households renting from the state/municipality pay rent which is substantially below the market rent, we cannot equalize them with owners, because home ownership is an important asset. Although this category of tenants have lower costs compared to those who rent private housing, the former cannot control their housing, which is a serious limitation on their opportunities, compared to homeowners.

${ }^{18}$ These standards are applied to calculate the size of the housing subsidy, one of the most important federal meanstested social allowances. The federal social standard equals 36 sq.m for a person living alone, 42 sq.m for a twoperson household and 18 sq.m per each person in households with three and more members.

${ }^{19}$ In a number of studies this item is included in the material deprivation measure, however, the difficulty in coping with expenses is likely to be influenced not only by the deficit of income, but also by individual coping skills, that is why we prefer to treat it as a subjective measure.

${ }^{20}$ Weights are equal to the squared factor loadings taken relatively to the total eigenvalue of the first factor.

21 The demographic composition variable was used to derive weights for domain indices, but in a reduced form that included only three broad categories: households with children under 18 years / households without children under 18 years / households of pensioners. 